bioRxiv preprint doi: https://doi org/101101/2020 07.20.212290; this version posted July 21,2020 . The copyright holder for this preprint

(which was not certified by peer review) is the author/funder, who has granted bioRxiv a license to display the preprint in perpetuity. It is made available under aCC-BY-NC-ND 4.0 International license.

\title{
1 Ivermectin inhibits extracellular vesicle secretion from parasitic nematodes
}

2

3 Hannah J. Loghry ${ }^{1}$, Wang Yuan ${ }^{1}$, Mostafa Zamanian², Nicolas J. Wheeler ${ }^{2}$,

4 Timothy A. Day ${ }^{1}$, Michael J. Kimber ${ }^{1 *}$

$5{ }^{1}$ Department of Biomedical Sciences, College of Veterinary Medicine, Iowa State University,

6 Ames, Iowa, United States of America

$7{ }^{2}$ Department of Pathobiological Sciences, University of Wisconsin-Madison, Madison, Wisconsin, 8 United States of America

9

*Corresponding author: michaelk@iastate.edu

11

12 This work was supported by the National Institutes of Health under Grant AI117204.

13

Word Count: 10,674 
bioRxiv preprint doi: https://doi org/10.1101/2020.07.20.212290; this version posted July 21, 2020. The copyright holder for this preprint (which was not certified by peer review) is the author/funder, who has granted bioRxiv a license to display the preprint in perpetuity. It is made available under aCC-BY-NC-ND 4.0 International license.

\section{Abstract}

Lymphatic filariasis (LF) is a disease caused by parasitic filarial nematodes that is endemic in 49 countries and affects or threatens over 890 million people. Strategies to control LF rely heavily on mass administration of anthelmintic drugs including ivermectin (IVM), a macrocyclic lactone drug considered an Essential Medicine by the WHO. However, despite its widespread use the therapeutic mode of action of IVM against filarial nematodes is not clear. We have previously reported that filarial nematodes secrete extracellular vesicles (EVs) and that their cargo has immunomodulatory properties. Here we investigate the effects of IVM and other anti-filarial drugs on parasitic nematode EV secretion, motility, and protein secretion. We show that inhibition of EV secretion was a specific property of IVM, which had consistent and significant inhibitory effects across nematode life stages and species (with the exception of male parasites). IVM inhibited EV secretion, but not parasite motility, at therapeutically relevant concentrations. Protein secretion was inhibited by IVM in the microfilariae stage, but not in any other stage tested. Our data provides evidence that inhibiting the secretion of immunomodulatory EVs by parasitic nematodes could explain, at least in part, IVM mode of action and provides a phenotype for novel drug discovery.

Keywords: ivermectin, macrocyclic lactone, extracellular vesicle, lymphatic filariasis, Brugia malayi, parasite 


\section{Introduction}

Lymphatic filariasis (LF) is a Neglected Tropical Disease caused by thread-like parasitic filarial nematodes, including Brugia malayi, that establish in the lymphatic vasculature. LF is often asymptomatic but symptoms manifest in approximately $40 \%$ of cases with lymphedema, hydrocoele, dermatitis and long-term disability characterizing clinical disease. It is estimated that LF is endemic in 49 countries and that over 890 million people are infected or at risk of infection (World Health Organization, 2019). In 2000 the Global Programme to Eliminate Lymphatic Filariasis was created with the goal of eliminating this disease by 2020 and although there has been reduction in the prevalence of LF in some areas this disease is far from being eliminated. Strategies to control LF and other filarial parasitic nematode infections rely heavily on mass administration of the anthelmintic drugs ivermectin (IVM), albendazole (ABZ) and diethylcarbamazine (DEC) in endemic areas. IVM is classified as an essential medication by the World Health Organization (World Health Organization, 2019) and since 2000, over 7 billion treatments have been delivered to at risk individuals (World Health Organization, 2019), however, this disease still remains an issue. One challenge to eliminating LF centers on the inadequate drugs that are currently available; neither IVM, ABZ or DEC effectively kill adult parasites, thus established infections are incurable.

Compounding this and despite their widespread use, the therapeutic modes of action of IVM, and to a lesser extent DEC, are not entirely clear.

A current working hypothesis for the therapeutic activity of IVM is that it inhibits the release of excretory-secretory (ES) products from parasites; this inhibition is postulated to "unmask" the parasite allowing for host recognition and parasite clearance (Moreno et al., 2010). In support is the acceptance that the host immune system is involved in filarial parasite elimination, especially in the clearance of microfilaria (mf) stage worms (Carithers, 2017; Wolstenholme et al., 2016) and data from experiments such as Berrafato et al. showing that IVM enhanced leukocyte binding to Dirofilaria immitis $\mathrm{mf}$ and Semnani et al. who showed that IVM could reverse the modified Th2 phenotypes caused in filaria infected patients (Berrafato et al., 2019; Semnani et al., 2006). There is 
widespread support that ES products from filarial nematodes do modulate host immune responses.

Early filarial nematode infection elicits a canonical Th2 immune response characterized by increased production of the cytokines interleukin (IL)-4, IL-5, IL-9, IL-10, and IL-13 and the antibody isotypes IgG1, IgG4 (in humans), and IgE and increased production of Th2 cells, eosinophils, alternatively activated macrophages, and innate lymphoid cells 2 (ILC2) (Allen \& Maizels, 2011; Geary et al., 2010). With development of chronic filarial infection the Th2 response becomes "modified" to a more tolerant, regulatory environment with increased IL-4, IL-10, $\mathrm{T}_{\text {reg }}$ and alternatively activated macrophage proliferation and reduction in IL-5, IL-13 and T cell proliferation coupled with T cell anergy and decreased antigen presenting capabilities (Babu \& Nutman, 2014). There is considerable evidence that filarial nematode parasites contribute to this "modified" phenotype but the exact parasite factors driving this manipulation remain uncertain.

Extracellular vesicles (EVs) are membrane-bound vesicles secreted into the extracellular environment by eukaryotic and prokaryotic cells. Although once thought to be carriers of waste products, it has been shown that EVs function in many physiological processes and are important mediators of cell-to-cell signaling (Bobrie et al., 2011; Lee et al., 2012; Raposo et al., 1996; Valadi et al., 2007). EVs are considered a heterogenous group of sub-cellular structures that can be subdivided based on size and biogenesis. Primary focus has been on two subsets of EVs, microvesicles that range from $150-1,500 \mathrm{~nm}$ and a smaller grouping (30-150 nm) originally termed exosomes (Johnstone et al., 1987). Exosomes are products of the endosomal pathway and are derived from multivesicular bodies (MVBs) that fuse with the cell membrane to secrete the vesicles into the extracellular space (Catalano \& O’Driscoll, 2020; Riaz \& Cheng, 2017; Vlassov et al., 2012). Consistent with a role in cell-to-cell communication, EVs contain diverse functional cargo that varies depending on the cellular origin of the EVs, but in general include bioactive proteins, RNA and lipids (Thery et al., 2002; Valadi et al., 2007). EV secretion from diverse parasitic nematodes has been described (Buck et al., 2014; Coakley et al., 2017; Eichenberger, Ryan, et al., 2018; Eichenberger, Talukder, et al., 2018; Gu et al., 2017; Hansen et al., 2015, 2019; Harischandra 
et al., 2018; Shears et al., 2018; Tritten et al., 2017; Tzelos et al., 2016; Zamanian et al., 2015) and the cargo of these EVs have immunomodulatory functions (Buck et al., 2014; Quintana et al., 2017; Tritten et al., 2016). We have previously reported that $B$. malayi secretes EVs and that their cargo has putative immunomodulatory properties (Harischandra et al., 2018; Zamanian et al., 2015).

Driven by these emerging data, EVs have been advanced as a potential mechanism by which parasites modulate host immune responses (Buck et al., 2014; Coakley et al., 2017; Eichenberger, Sotillo, et al., 2018; Harischandra et al., 2018).

We propose that nematode EVs are essential for filarial nematode parasitism and hypothesize that effective anti-filarial drugs inhibit their secretion. To investigate this hypothesis, a panel of antifilarial drugs was screened for their ability to reduce EV secretion from parasitic nematodes. We found that IVM had the most consistent inhibitory effects on EV secretion by various species and life stages of parasite. Importantly, however, IVM had insignificant effects on motility and limited effects on protein secretion at therapeutically relevant concentrations and timepoints. These observations provide insight into the mechanism of action of IVM and may support prioritizing inhibition of EV secretion as a screenable phenotype for novel anti-filarial drug development.

\section{Materials and Methods}

\subsection{Parasite culture and maintenance}

Brugia malayi and B. pahangi parasites were obtained from the NIH/NIAID Filariasis Research Reagent Resource Center (FR3) at the University of Georgia, USA. Persistent B. malayi infections at FR3 are maintained in domestic short-haired cats. To obtain adult stage B. malayi jirds were infected intraperitoneally with approximately 400 L3 stage parasites. 120 days post-infection jirds were necropsied to collect adult stage parasites. L3 stage $B$. malayi were obtained from dissection of anesthetized Aedes aegypti 14 days post-infection. Microfilaria stage B. malayi were obtained 
from a lavage of the peritoneal cavity of a euthanized gerbil. B. pahangi stages were obtained in the same manner as B. malayi with the exception that infective L3 stage parasites were collected 11 days and 16 days post-infection, respectively. The $B$. malayi parasite supply from FR3 was supplemented with parasites from TRS Labs LLC (Athens, Georgia, USA). These supplemental parasites were tested and responded to treatments in the same manner as parasites from FR3. Upon receipt at ISU, all B. malayi and B. pahangi parasites were washed several times in warmed worm culture media (RPMI with 1\% HEPES, $1 \%$ L-glutamine, $0.2 \%$ Penicillin/Streptomycin, and 1\% w/v glucose [all Thermo Fisher Scientific, Waltham, MA]) and then counted and cultured at $37^{\circ} \mathrm{C}$ with 5\% $\mathrm{CO}_{2}$. Adult female Ascaris suum were collected from an abattoir in Marshalltown, Iowa, USA. These parasites were washed multiple times in warmed Ascaris Ringer's Solution (13.14 mM NaCl, $9.67 \mathrm{mM} \mathrm{CaCl}_{2}, 7.83 \mathrm{mM} \mathrm{MgCl}_{2}, 12.09 \mathrm{mM} \mathrm{C}_{4} \mathrm{H}_{11} \mathrm{NO}_{3}, 99.96 \mathrm{mM} \mathrm{C}_{2} \mathrm{H}_{3} \mathrm{NaO}_{2}, 19.64 \mathrm{mM} \mathrm{KCl}$ with Gentamycin $(100 \mu \mathrm{g} / \mathrm{ml})$, Ciprofloxacin Hydrochloride $(20 \mu \mathrm{g} / \mathrm{ml})$, penicillin $(10,000$ units/ml), streptomycin $(10,000 \mu \mathrm{g} / \mathrm{ml})$, and Amphotericin B $(25 \mu \mathrm{g} / \mathrm{ml})$ at $\mathrm{pH} 7.87$ [all SigmaAldrich, St Louis, MO]) and then incubated overnight at $34^{\circ} \mathrm{C}$. After $24 \mathrm{hrs}$ in culture the parasites were checked for visible signs of bacterial or fungal contamination; if present the parasites were discarded.

\subsection{Drug treatments of parasites}

Parasites were cultured in the presence or absence of drug to examine effects on extracellular vesicle (EV) secretion. For B. malayi and B. pahangi, 10 adult female and 10 adult males were cultured as previously described for $24 \mathrm{hrs}$ in $10 \mathrm{ml}$ and $3 \mathrm{ml}$ culture media, respectively, in $15 \mathrm{ml}$ polypropylene centrifuge tubes (Thermo Fisher Scientific). 100 L3 or $1 \times 10^{6}$ microfilariae were cultured as previously described for $24 \mathrm{hrs}$ in $1 \mathrm{ml}$ culture media in $1.5 \mathrm{ml}$ microcentrifuge tubes (Thermo Fisher Scientific). Single adult female A. suum were cultured in $100 \mathrm{ml}$ culture media in $250 \mathrm{ml}$ sterile Erlenmeyer flask for $24 \mathrm{hrs}$ as previously described. Four drugs, ivermectin, albendazole, diethylcarbamazine, and levamisole (all Sigma-Aldrich) were investigated for their 
135 effects on each life stage of the parasite species. The various drugs or DMSO (vehicle control) were 136 added to the culture media at a final concentration of $1 \mu \mathrm{M}$ and $0.01 \%$ respectively for screening 137 purposes. Spent media was collected after a $24 \mathrm{hr}$ incubation. Additionally, drug and control treated 138 A. suum and B. pahangi media was collected at 2, 4, 6, and 12-hr intervals to investigate the time 139 course of the effects of the drugs. A dose curve for the effects of ivermectin on B. malayi were 140 conducted in the same manner as described above with concentrations ranging from $0.1 \mathrm{nM}-10$ $141 \mu \mathrm{M}$.

\subsection{EV Isolation and Quantification}

EVs were collected as previously described using differential ultracentrifugation (Harischandra et al., 2018; Zamanian et al., 2015). Media was filtered through $0.2 \mu \mathrm{m}$ PVDF filtered syringes (GE Healthcare, Chicago, IL) or PVDF vacuum filters (Sigma-Aldrich) and centrifuged at 120,000 x $g$ for 90 minutes at $4^{\circ} \mathrm{C}$. The supernatant was decanted leaving approximately $1.5 \mathrm{ml}$ media to ensure that the EV pellet was not disrupted. The retained media and pellet were filtered through a PVDF $0.2 \mu \mathrm{m}$ syringe filter and centrifuged at $186,000 \mathrm{x} g$ for a further two hrs at $4^{\circ} \mathrm{C}$. Pelleted EV samples were resuspended to $500 \mu \mathrm{l}$ in dPBS (Thermo Fisher Scientific). EV quantification and size determination were performed using nanoparticle tracking analysis (NTA; Nano-Sight LM10, Malvern Instruments, Malvern, UK).

\subsection{Motility Analysis}

155 The Worminator system developed and described by Marcellino et al. (2012) was used to 156 quantitatively measure motility of adult filarial nematodes in microtiter plates. Microscopic parasite 157 life stages were quantitatively analyzed by the same software, but with methods previously described by Storey et al. (2014). Briefly, a single adult male or female worm was cultured in one 
well of a standard 24-well cell culture plate (Sigma-Aldrich). For infective L3 stage worms, 10 worms were cultured per well of a 96-well plate (Corning Inc, Corning, NY). Drug or DMSO (vehicle control) was added to each well to a final concentration of $1 \mu \mathrm{M}$ or $0.01 \%$ respectively. Worms were incubated at $37^{\circ} \mathrm{C}$ and $5 \% \mathrm{CO}_{2}$ and measurements were briefly taken, at room temperature, prior to treatment, immediately after treatment ( $0 \mathrm{hrs})$ and at 2, 4, 6 and 24-hrs post treatment. Measurements of the effects of doses of ivermectin ranging from $0.1 \mathrm{nM}-10 \mu \mathrm{M}$ on adult female B. malayi were conducted at $24 \mathrm{hrs}$ post treatment.

\subsection{SF21 Cell Culture}

Sf21 cells (Thermo Fisher Scientific) were maintained in Ex-Cell 420 serum free media (Sigma Aldrich) with $1 \%$ Penicillin/Streptomycin and $0.25 \mathrm{ug} / \mathrm{ml}$ Amphotericin B. Cells were seeded at a density of $3 \times 10^{5}$ cells/well in a 6-well plate. After an overnight incubation at $28^{\circ} \mathrm{C}$, cells were either treated with a final concentration of $1.0 \mu \mathrm{M}$ ivermectin, $0.1 \mu \mathrm{M}$ ivermectin or $0.01 \%$ DMSO (vehicle control). Spent media was collected after $24 \mathrm{hrs}$ and processed for EV isolation as described above with the addition of an initial centrifugation step of 12,000 x $g$ for 30 minutes at $4^{\circ} \mathrm{C}$ to eliminate cellular debris.

\subsection{Protein Quantification Assay}

A single B. malayi adult or 100,000 microfilariae were cultured per well of a 24 -well plate with either drug or DMSO at a final concentration of $1.0 \mu \mathrm{M}$ or $0.01 \%$, respectively, for $24 \mathrm{hrs}$. A concentration-response curve for ivermectin was conducted on adult female worms with concentrations ranging from $0.1 \mathrm{nM}-10 \mu \mathrm{M}$. Spent media was collected and filtered through a 0.2 $\mu \mathrm{M}$ PVDF membrane filter (GE Healthcare) $500 \mu \mathrm{l}$ of media were concentrated using a $0.5 \mathrm{~mL}$, 
instructions. Media samples were concentrated by centrifuging at 14,000 x $g$ for 30 minutes.

Samples were then washed with $500 \mu \mathrm{l} \mathrm{dPBS}$ for 30 minutes at 14,000 x $g$. The washing step was repeated four times. The volume of each sample was determined, and all samples were normalized to $150 \mu \mathrm{l}$ with dPBS. Adult female samples were then further diluted 4-fold with dPBS while adult male, L3 stage and microfilariae were diluted 2-fold with dPBS to ensure that readings would fall within the standard curve. Total protein was quantified with Pierce micro BCA kit (Thermo Fisher Scientific) according to manufacturers' instructions. Protein assay plates were quantified using a SpectraMax M2e plate reader (Molecular Devices, San Jose, CA).

\subsection{Statistical Analysis}

Due to some variation among individual parasites and between batches of parasites, experiments were conducted across multiple batches of parasite shipments, with each $\mathrm{N}$ representing parasites from independent shipments. Individual control and treated worms within each batch were paired together to help account for batch variation. EV NTA data was analyzed via a ratio-paired T-test with p-values less than 0.05 being considered significant. Non-linear regressions with least squares fit were used to analyze the dose response curves for ivermectin on B. malayi adult female EV secretion, motility, and protein secretion. Motility data was analyzed via a RM 2-way ANOVA with Geisser-Greenhouse correction followed by a Dunnet's multiple comparison test. Paired T-test between each treatment for each life stage were used to analyze data from the protein assay as the data contained values unsuited for a ratio-paired T-test. Due to the variability among batches and individual parasites the ROUT outlier identification method was used to identify outliers in the data $(\mathrm{Q}=0.5 \%)$. All statistical analyses were performed using Prism 8.4.1. (GraphPad Software, San Diego, CA). 
bioRxiv preprint doi: https://doi org/10.1101/2020.07.20.212290; this version posted July 21, 2020. The copyright holder for this preprint (which was not certified by peer review) is the author/funder, who has granted bioRxiv a license to display the preprint in perpetuity. It is made available under aCC-BY-NC-ND 4.0 International license.

\subsection{Ivermectin inhibits EV secretion from Brugia malayi in a sex- and stage- specific manner}

In this study we investigated the effects of ivermectin (IVM) on B. malayi EV secretion in vitro.

Parasites were cultured at $37^{\circ} \mathrm{C}$ in the presence or absence of IVM and the number of EVs secreted by the worms was quantified by nanoparticle tracking analysis (NTA). An initial screening concentration of $1.0 \mu \mathrm{M}$ IVM significantly reduced $\mathrm{EV}$ secretion after 24 hrs incubation from $B$. malayi adult females by $59 \%(\mathrm{p}=0.0204, \mathrm{~N}=13)$ and from L3 stage parasites by $31 \%(\mathrm{p}=0.0067$, $\mathrm{N}=19)$. There was no significant effect on EV secretion from adult male $(\mathrm{p}=0.4028, \mathrm{~N}=10)$ or microfilariae $(\mathrm{mf})(\mathrm{p}=0.2081, \mathrm{~N}=13)$ life stages (Fig 1A-D). The IVM concentration response in adult female $B$. malayi was further profiled and the $\mathrm{IC}_{50}$ determined to be $7.7 \mathrm{nM}$ (Fig 1E). Studies conducted on the pharmacokinetics of a single dose of IVM in human subjects have determined serum levels to be between 20-70 nM (González Canga et al., 2008). IVM therefore inhibits EV secretion in adult female parasites at therapeutically relevant concentrations suggesting that this phenomenon may contribute to IVM therapeutic mode of action.

These observations on the inhibitory effect of IVM on EV secretion from adult female and L3 stage B. malayi generally align with preliminary data previously reported, (Harischandra et al., 2018) with the exception of the lack of inhibition in adult males and a reduced inhibition in mf stages. The previously reported inhibitory effect on EV secretion from adult males was marginal, but the lack of effect on $\mathrm{mf}$ is more surprising considering its prior robustness. Previously, mf were incubated with IVM at ambient temperature whereas here they were incubated at $37^{\circ} \mathrm{C}$. To test the impact of temperature on the IVM phenotype in $\mathrm{mf}$, we repeated the $\mathrm{mf}$ IVM incubation at ambient temperature. Unlike at $37^{\circ} \mathrm{C}, 1.0 \mu \mathrm{M}$ IVM significantly inhibited EV secretion by $46 \%(\mathrm{p}=0.0177$, $\mathrm{N}=8)$ at ambient temperature $\left(22^{\circ} \mathrm{C}\right)(\mathrm{Fig} 2 \mathrm{~A})$. Control and treated parasites were still viable at the end of the experiment indicating that it was not loss of viability or death of the parasites that had caused inhibition of EV secretion. There are clear temperature-dependent effects on EV secretion from $\mathrm{mf}$ stage worms, not only did incubation of $\mathrm{mf}$ at $37^{\circ} \mathrm{C}$ abrogate the inhibitory effect of IVM on EV secretion, but it also increased EV secretion in untreated worms by approximately a factor of 
bioRxiv preprint doi: https://doi org/10.1101/2020.07.20.212290; this version posted July 21, 2020. The copyright holder for this preprint (which was not certified by peer review) is the author/funder, who has granted bioRxiv a license to display the preprint in perpetuity. It is made available under aCC-BY-NC-ND 4.0 International license.

7. Whilst logical to assume temperature changes impact worm physiology, there is a lack of data on the effects of temperature on specific processes and functions in mf stage nematodes. We do know that host temperature has no effect on the nocturnal periodicity of mf (Hawking, 1967) or on the ability of mf to bind to vascular endothelial cells (Schroeder et al., 2017). Environmental temperature may affect other physiological processes in mf leading to this increased production of $\mathrm{EVs}$, but further investigation into this phenomenon is necessary.

This temperature-dependent effect in mf prompted further efforts to determine the mechanism by which IVM is inhibiting EV secretion. One hypothesis is IVM inhibits EV biogenesis in these parasites. Nematode cell lines that might provide an opportunity to interrogate EV biogenesis are lacking so Sf21cells from the army fallworm, Spodoptera frugiperda, were used as an ecdysozoan surrogate to examine the effect of IVM on EV biogenesis in vitro. Sf21 cells were treated with high $(1.0 \mu \mathrm{M})$ and low $(0.1 \mu \mathrm{M})$ concentrations of IVM and EV secretion was analyzed by NTA after 24 hrs. Neither concentration of IVM inhibited EV secretion from Sf21 cells (Fig 2B), perhaps suggesting the drug does not directly impact EV biogenesis. Another hypothesis is that IVM disrupts the location from where EVs are secreted. The physical characteristics of EVs produced from IVM-treated or DMSO-treated B. malayi adult females were analyzed by NTA. Although EVs are, as a whole, a heterogenous population in regards to size, our data suggested that there was no obvious shift in EV size profile following IVM treatment (Fig 2C). It might be expected that disrupting the location from where EVs are secreted, for example the parasite GI tract or reproductive structures, might alter their physical characteristics, but this was not observed. The physical characteristics of EVs secreted by other B. malayi life stages were also analyzed (Supplemental Figure 2A-C). Consistent with the adult female data, there were no differences in EV size following IVM treatment of any life stage. Collectively, our data suggests that IVM works not by altering EV biogenesis or changing the location from where EVs are secreted, but rather restricts the numbers of EVs being secreted by pre-existing pathways. 
bioRxiv preprint doi: https://doi org/10.1101/2020.07.20.212290; this version posted July 21, 2020. The copyright holder for this preprint (which was not certified by peer review) is the author/funder, who has granted bioRxiv a license to display the preprint in perpetuity. It is made available under aCC-BY-NC-ND 4.0 International license.

\subsection{Other drugs with anti-filarial activity do not inhibit EV secretion from B. malayi}

To examine if inhibition of EV secretion is a general feature of drugs with anti-filarial activity, we tested a panel of drugs with known anti-filarial activity including albendazole (ABZ), diethylcarbamazine (DEC) and levamisole (LEV). LEV is a nicotinic agonist and although more typically used to treat gastrointestinal nematode infection, was included in the panel because it is an anthelmintic drug with known neuromuscular effects on filarial nematodes (Martin, 1997;

Robertson et al., 2013) and also because of reported microfilaricidal effects on canine heartworm, D. immitis (Carlisle et al., 1984; Mills \& Amis, 1975). Parasites were cultured with or without an initial screening concentration of $1.0 \mu \mathrm{M}$ drug and EVs were quantified using NTA. 1.0 $\mu \mathrm{M}$ DEC significantly increased EV secretion from B. malayi $\mathrm{mf}$ by $43 \%(\mathrm{p}=0.0177, \mathrm{~N}=7)$ after $24 \mathrm{hrs}$ (Fig 1D). DEC also seemed to increase EV secretion in L3 (Fig 1C) though not significantly ( $\mathrm{p}=$ 0.2236, $\mathrm{N}=10$ ). Additionally, DEC had a moderate, but not significant, inhibition on EV secretion in adult females $(\mathrm{p}=0.1704, \mathrm{~N}=10)$ and had no effect on adult males $(\mathrm{p}=0.2323, \mathrm{~N}=9)($ Fig $1 \mathrm{~A}$ B). There was a minor, but not significant, inhibition of EV secretion due to $\mathrm{ABZ}$ on B. malayi adult females ( $\mathrm{p}=0.4042, \mathrm{~N}=10), \mathrm{L} 3(\mathrm{p}=0.1564, \mathrm{~N}=11)$, and $\mathrm{mf}(\mathrm{p}=0.7815, \mathrm{~N}=7)(\mathrm{Fig}$ 1A,C,D). In contrast, ABZ treatment seemed to increase EV secretion from adult males (Fig 1B) though not significantly $(\mathrm{p}=0.0821, \mathrm{~N}=9$ ). LEV did not have an effect on EV secretion from either male $(\mathrm{p}=0.1091, \mathrm{~N}=11)$ or female adults $(\mathrm{p}=0.8659, \mathrm{~N}=9)($ Fig 1A-B $)$. L3 stage parasites showed a minor although not significant inhibition in EV secretion due to LEV treatment $(\mathrm{p}=$ 0.0719, $\mathrm{N}=10$ ) while $\mathrm{mf}$ had a moderate, but not significant increase in EV secretion due to LEV treatment $(\mathrm{p}=0.0770, \mathrm{~N}=7)($ Fig $1 \mathrm{C}-\mathrm{D})$. In summary, none of the drugs in the panel significantly inhibited EV secretion from any of the B. malayi life stages when tested at $1.0 \mu \mathrm{M}$, except for DEC which significantly increased EV secretion from B. malayi microfilariae. This is significant because it suggests that inhibition of EV secretion by filarial nematodes may be a phenotype specific to IVM treatment and is not observed upon treatment with other anthelmintic drugs that are known to have anti-filarial activity, including a drug (LEV) that has clear neuromuscular effects on filarial worms. 
bioRxiv preprint doi: https://doi org/10.1101/2020.07.20.212290; this version posted July 21, 2020. The copyright holder for this preprint (which was not certified by peer review) is the author/funder, who has granted bioRxiv a license to display the preprint in perpetuity. It is made available under aCC-BY-NC-ND 4.0 International license.

This helps support the hypothesis that the mechanism of action of IVM, and perhaps other macrocyclic lactones, includes inhibition of EV secretion.

\subsection{Ivermectin has broad inhibitory effects on EV secretion across other filarial and} gastrointestinal nematode parasites

To test whether the inhibitory IVM phenotype in B. malayi was broadly consistent in nematodes, we repeated the same screening experiment with our same drug panel using first a related species of filarial nematode, B. pahangi. Our analysis was limited to B. pahangi adult females, adult males and mf based on worm availability. All drugs in the panel significantly inhibited EV secretion from $B$. pahangi adult female parasites. IVM treatment had the greatest reduction in EV secretion with an inhibition of $63 \%(\mathrm{p}=0.0083, \mathrm{~N}=10)$, while ABZ had an inhibition of $61 \%(\mathrm{p}=0.0066, \mathrm{~N}=12)$, DEC by $59 \%(\mathrm{p}=0.0322, \mathrm{~N}=12)$ and LEV by $44 \%(\mathrm{p}=0.0416, \mathrm{~N}=11)($ Fig $3 \mathrm{~A})$. The IVM, ABZ and DEC results generally paralleled the trends seen in B. malayi adult females, but with LEV now also active. Neither IVM $(p=0.9897, \mathrm{~N}=11), \mathrm{ABZ}(\mathrm{p}=0.9369, \mathrm{~N}=13), \mathrm{DEC}(\mathrm{p}=0.0925, \mathrm{~N}$ = 12), nor LEV ( $\mathrm{p}=0.7558, \mathrm{~N}=11$ ) had any effect on adult male $B$. pahangi (Fig 3B). Again, this is consistent with the results seen in B. malayi adult male parasites. In mf stage B. pahangi, IVM significantly reduced $\mathrm{EV}$ secretion by $40 \%$ at $37^{\circ} \mathrm{C}(\mathrm{p}=0.0358, \mathrm{~N}=4)(\mathrm{Fig} 3 \mathrm{C})$, which contrasts sharply with what was seen in B. malayi $\mathrm{mf}$ and perhaps better aligns with the expected bioactivity of IVM at this life stage (Moreno et al., 2010). While DEC significantly increased EV secretion in B. malayi $\mathrm{mf}$ it did not have any effect on B. pahangi $\mathrm{mf}(\mathrm{p}=0.6428, \mathrm{~N}=3)($ Fig 3C). Lastly, ABZ $(\mathrm{p}=0.6605, \mathrm{~N}=3)$ and LEV $(\mathrm{p}=0.4125, \mathrm{~N}=3)$ had no effect on EV secretion from B. pahangi $\mathrm{mf}$ (Fig 3C). To investigate whether the inhibitory effects of IVM on EV secretion were seen in more divergent nematode species we again repeated our screen on single adult female Ascaris suum, a soil-transmitted gastrointestinal nematode. $\operatorname{IVM}(\mathrm{p}=0.0013, \mathrm{~N}=14)$ and LEV $(\mathrm{p}=0.0021, \mathrm{~N}=16)$ both significantly inhibited EV secretion from individual adult female $A$. suum after 24 hrs by 
99.4\% and 99.1\% respectively (Fig 3E). However, neither ABZ $(\mathrm{p}=0.3769, \mathrm{~N}=12)$ nor DEC $(\mathrm{p}=$ $0.9680, \mathrm{~N}=16)$ had any effect on EV secretion (Fig 3E).

The size characteristics of those EVs that continued to be secreted by both adult female $B$. pahangi (Fig 3D) and A. suum (Fig 3F) following IVM treatment was examined using NTA. As was seen in B. malayi, IVM did not affect the physical characteristics of EVs produced from these other species of parasites, providing additional evidence that the inhibitory bioactivity of IVM may not be involved in changing from where EVs are secreted. The effects of the other drugs in our screening panel on the size of EVs secreted by B. malayi and B. pahangi life stages were also analyzed (Supplemental Fig 2A-E). None of the drugs tested had any effect on the physical characteristics of EVs secreted.

B. pahangi and A. suum adult female worms secrete EVs more robustly than B. malayi. In the case of A.suum, they secrete approximately 250 times more EVs than B. malayi in 24 hrs. This positioned us to use these two species to better understand how rapidly IVM inhibits EV secretion from susceptible parasitic nematodes. Adult female B. pahangi and A.suum parasites were treated with $1.0 \mu \mathrm{M}$ IVM as before and spent media collected at 2, 4, 6, 12 and 24 hrs post IVM treatment. IVM significantly inhibited both B. pahangi and A. suum EV secretion by $63 \%(\mathrm{p}=0.0076, \mathrm{~N}=3)$ and $99.4 \%(\mathrm{p}=0.0054, \mathrm{~N}=3)$, respectively, at the $24 \mathrm{hrs}$ post-treatment timepoint (Fig 3G-H). In addition, EV secretion was inhibited as early as at 12 hours post-treatment by $72 \%(\mathrm{p}=0.1929, \mathrm{~N}=$ 3) for A. suum and by $57 \%(\mathrm{p}=0.0762, \mathrm{~N}=3)$ for $B$. pahangi, though not statistically significant (Fig 3G-H). In vivo studies have shown IVM reduces microfilaremia in mice experimentally infected with B. malayi 24 hrs post-treatment (Halliday et al., 2014). Thus, the rapidity of onset for this EV secretion phenotype is consistent with the therapeutic action of IVM. For context, other IVM phenotypes have been identified at 24 hrs post-treatment timepoint, in vitro IVM reduces the release of B. malayi $\mathrm{mf}$ from adult female worms (Tompkins et al., 2010) and increases the binding of polymorphonuclear leukocytes to B. malayi mf (Berrafato et al., 2019) after $24 \mathrm{hrs.} \mathrm{In} \mathrm{canine}$ 
bioRxiv preprint doi: https://doi org/10.1101/2020.07.20.212290; this version posted July 21, 2020. The copyright holder for this preprint (which was not certified by peer review) is the author/funder, who has granted bioRxiv a license to display the preprint in perpetuity. It is made available under aCC-BY-NC-ND 4.0 International license.

heartworms, IVM inhibits the motility of Missouri strain D. immitis $24 \mathrm{hrs}$ post-treatment in vitro (Maclean et al., 2017).

\subsection{Ivermectin inhibition of EV secretion is not driven by loss of gross motor function}

Glutamate-gated chloride channels $(\mathrm{GluCl})$ and nicotinic acetylcholine receptors (nAChRs), are known targets for IVM and LEV, respectively (Arena et al., 1991, 1992; Harrow \& Gration, 1985).

$\mathrm{GluCl}$ have been identified in motor neurons and interneurons in various parasitic nematode species (Adrian J. Wolstenholme \& Rogers, 2005) and nAChRs have been identified at the neuromuscular junction in filarial nematodes (Martin, 1997). Their locations lead to the discovery that IVM can induce paralysis of pharyngeal pumping in Haemonchus contortus (Geary et al., 1993) and both IVM and LEV can cause paralysis of B. malayi parasites (Mostafa et al., 2015; Tompkins et al., 2010). Due to these documented effects it is plausible that the EV phenotype is driven by gross motor function defects. To test this we examined the effect of our screening panel on gross motor function by analyzing motility quantified using the Worminator software system (Marcellino et al., 2012). Our analysis was limited to B. malayi adults and L3 stage parasites due to parasite availability and difficulties in consistently recording the smaller mf life stage. A single B. malayi adult or 10 L3 stage parasites were cultured in a 24-well or 96-well plate respectively with or without $1.0 \mu \mathrm{M}$ drug. Video recordings were taken prior to treatment, immediately after treatment ( $0 \mathrm{hrs}$ ), and at 2, 4, 6 and $24 \mathrm{hrs}$ post-treatment. IVM significantly reduced adult female motility by $57 \%$ beginning at $4 \mathrm{hrs}$ post-treatment $(\mathrm{p}<0.0001, \mathrm{~N}=5)($ Fig $4 \mathrm{~A})$. However, when the kinetics of IVM treatment on adult female parasites was investigated it was observed that more therapeutically relevant concentrations did not affect motility (Fig 4D). This is corroborated by other data that shows that motility of $B$. malayi parasites was not inhibited by concentrations of IVM less than 2 $\mu \mathrm{M}$ (Storey et al., 2014; Tompkins et al., 2010). This provides additional evidence that therapeutically relevant concentrations of IVM do not affect filarial nematode motility. The IC 50 for IVM was determined to be $0.203 \mu \mathrm{M}$. The $\mathrm{IC}_{50}$ for $\mathrm{EV}$ secretion $(7.7 \mathrm{nM})$ was below that of 
bioRxiv preprint doi: https://doi org/10.1101/2020.07.20.212290; this version posted July 21, 2020. The copyright holder for this preprint (which was not certified by peer review) is the author/funder, who has granted bioRxiv a license to display the preprint in perpetuity. It is made available under aCC-BY-NC-ND 4.0 International license.

motility indicating that IVM is not reducing EV secretion by paralyzing the parasites. DEC ( $p<$ $0.001, \mathrm{~N}=5$ ) significantly inhibited adult female motility immediately upon treatment, but parasites began to recover at one $\mathrm{hr}(\mathrm{p}<0.01, \mathrm{~N}=5)$ and completely recovered by 4 hrs post-treatment. LEV $(\mathrm{p}<0.001, \mathrm{~N}=5)$ significantly inhibited adult female motility by $88 \%$ immediately upon treatment, but parasites began to recover during the remaining $24 \mathrm{hrs}$. At one hr post treatment LEV significantly inhibited adult female motility by $71 \%$, at four hrs by $40 \%$, at six hrs by $35 \%$ and at 24 hrs by $29 \%$ (1-6 hrs post-treatment: $\mathrm{p}<0.0001, \mathrm{~N}=5 ; 24$ hrs: $\mathrm{P}<0.01, \mathrm{~N}=5$ ). As was discussed earlier, no drug in our panel had any effect on EV secretion in adult male B. malayi, but it was discovered that LEV was a potent inhibitor of motility in adult male B. malayi (Fig 4B). Motility in adult males was significantly inhibited by $70 \%$ upon treatment with LEV. Adult male parasites treated with LEV did not recover with significant inhibition ranging from $70-76 \%$ over the 24 hrs tested (1-24 hrs post treatment: $\mathrm{p}<0.0001, \mathrm{~N}=5$ ). The only drug that had any effect on B. malayi $\mathrm{L} 3$ parasites was also LEV with inhibition of motility by $90 \%$ immediately upon treatment $(\mathrm{p}<0.001$, $\mathrm{N}=5$ ) (Fig 4C). However, a very quick recovery of motility was seen in just one hour. In summary, $1.0 \mu \mathrm{M}$ IVM had inhibitory effects on $B$. malayi adult female motility, but this concentration does not compare to therapeutically relevant concentrations or to the concentrations that inhibited EV secretion. LEV also had inhibitory effects on motility in all life stages tested, but adult female and L3 life stages recovered over 24 hrs while adult males did not recover. Due to the differences in IVM effects on motility compared to EV secretion we can conclude that inhibition of EV secretion is not a factor of parasite gross motor function being compromised.

\subsection{Ivermectin does not have parallel effects on EV and protein secretion}

Data indicate that IVM and ABZ inhibit protein secretion from B. malayi mf (Moreno et al., 2010). We have already shown that IVM can inhibit EV secretion from B. malayi so we hypothesized that excretory-secretory (ES) proteins and EVs would similarly be affected by the screening drug panel. Parasites were cultured with or without drug and ES protein secreted into the culture media was 
bioRxiv preprint doi: https://doi org/10.1101/2020.07.20.212290; this version posted July 21, 2020. The copyright holder for this preprint (which was not certified by peer review) is the author/funder, who has granted bioRxiv a license to display the preprint in perpetuity. It is made available under aCC-BY-NC-ND 4.0 International license.

quantified $24 \mathrm{hrs}$ after treatment using BCA. We chose to examine the $24 \mathrm{hr}$ time point as it is the most consistent with IVM therapeutic mechanism of action. Unlike EV secretion, neither $1.0 \mu \mathrm{M}$ $\operatorname{IVM}(p=0.8152, \mathrm{~N}=5), \operatorname{ABZ}(\mathrm{p}=0.9962, \mathrm{~N}=5), \operatorname{DEC}(\mathrm{p}=0.8863, \mathrm{~N}=5)$ or LEV $(\mathrm{p}=0.1571, \mathrm{~N}$ =5) had any effect on protein secretion from B. malayi adult females (Fig 5A,D). Similarly, no effect of any drug on protein secretion was observed in adult males (IVM p $=0.9400, \mathrm{~N}=5, \mathrm{ABZ} p$ $=0.4906, \mathrm{~N}=5, \mathrm{DEC} \mathrm{p}=0.9902, \mathrm{~N}=5, \mathrm{LEV} \mathrm{p}=0.8043, \mathrm{~N}=5)($ Fig $5 \mathrm{~B})$. Inhibition of ES protein secretion from $B$. malayi $\mathrm{mf}$ was noted after treatment with $1.0 \mu \mathrm{M} \operatorname{IVM}(23 \%, \mathrm{p}=0.0535, \mathrm{~N}=5)$ (Fig 5C), however, ABZ had no effect on protein secretion $(\mathrm{p}=0.5827, \mathrm{~N}=5)$. DEC $(0.5789, \mathrm{~N}=5)$ and LEV ( $\mathrm{p}=0.1648, \mathrm{~N}=5$ ) also had no inhibitory effect on ES protein secretion from B. malayi mf. The data do not exactly correlate to previously published work describing clear inhibitory effects of IVM and ABZ protein release from B. malayi mf (Moreno et al., 2010). The assay we used to quantify ES protein secretion from $B$. malayi was slightly modified from that study but was fundamentally the same. Despite tight technical replication, there was challenging biological variability between worm batches and the low quantities of ES protein secreted necessitated a concentration step, potentially exacerbating variability. Despite this, we have high confidence in comparing this data with those of Moreno et al (2010). Both studies observed a rapid inhibition of ES protein secretion from B. malayi mf following $24 \mathrm{hr}$ treatment with $1.0 \mu \mathrm{M} \mathrm{IVM}$, although our observed inhibition was moderately higher at $23 \%$ inhibition than Moreno et al with $14 \%$. Further, Moreno et al described an inhibitory effect of ABZ (more potent than that of IVM) that was not observed here.

\section{Discussion}

IVM is a broad spectrum, anti-parasitic drug that is commonly used to treat and prevent multiple diseases caused by parasitic nematodes. Even with its extensive usage, the therapeutic mechanism of action of this drug is not completely understood (Wolstenholme et al., 2016). The current accepted hypothesis is that it functions, at least in part, by inhibiting secretion of ES proteins from 
bioRxiv preprint doi: https://doi org/10.1101/2020.07.20.212290; this version posted July 21, 2020. The copyright holder for this preprint (which was not certified by peer review) is the author/funder, who has granted bioRxiv a license to display the preprint in perpetuity. It is made available under aCC-BY-NC-ND 4.0 International license.

parasites thereby "unmasking” the parasites and facilitating host clearance (Moreno et al., 2010).

Recent work has led to the characterization of the B. malayi secretome which, combined with RNA sequencing approaches, has defined a complex milieu of proteins and miRNAs secreted from these and other filarial parasites (Bennuru et al., 2009; Hewitson et al., 2008; Hoy et al., 2014; Kaushal et al., 1982; Tritten et al., 2016). Within this heterogenous mix of ES products are documented host immunomodulatory effectors, including leucyl aminopeptidase (ES-62) and macrophage inhibiting factor 1 (MIF-1), among others (Harnett et al., 1998; Lal et al., 1990; Pastrana et al., 1998).

Therefore, the observation that IVM can inhibit the secretion of immunomodulatory ES products is consistent with the rapid mf clearance observed after treatment in infected individuals. Although there is evidence tying the inhibition of ES product secretion to the mode of action of IVM, the critical ES products being inhibited are not immediately clear. In addition to freely secreted proteins, we have identified that prodigious numbers of EVs are also found in the ES products of filarial nematodes (Zamanian et al., 2015). In this study we show that IVM significantly and consistently inhibits EV secretion from B. malayi adult female, L3 and $\mathrm{mf}$ life stages, from $B$. pahangi adult females and mfs, and from female gastrointestinal A. suum nematodes. This inhibition occurs at therapeutically relevant concentrations $\left(\mathrm{IC}_{50}=7.7 \mathrm{nM}\right.$ in adult female $B$. malayi) and time frame (within $24 \mathrm{hrs}$ and perhaps even by $12 \mathrm{hrs}$ ). Given these properties, it is reasonable to hypothesize that the therapeutic mechanism of action of IVM against filarial nematodes may, in part, involve inhibition of EV secretion. Although premature, there is growing evidence to support this hypothesis. First, filarial nematode EVs are discrete structures that are enriched in immunomodulatory molecules. The cargo of B. malayi EVs includes proteins and miRNAs that have immunomodulatory functions and include modulatory proteins such as galectins and MIF-1 as well as miRNAs with identity to immunomodulatory host miRNAs (Harischandra $e t$ al., 2018; Zamanian et al., 2015). EVs from other nematode species are similarly imbued; protein and small RNA profiling of EV cargo from a range of gastrointestinal and filarial nematodes reveals a multitude of putative effector molecules with emerging functionality at the host-parasite interface 
bioRxiv preprint doi: https://doi org/10.1101/2020.07.20.212290; this version posted July 21, 2020. The copyright holder for this preprint (which was not certified by peer review) is the author/funder, who has granted bioRxiv a license to display the preprint in perpetuity. It is made available under aCC-BY-NC-ND 4.0 International license.

(Buck et al., 2014; Eichenberger, Ryan, et al., 2018; Eichenberger, Talukder, et al., 2018; Gu et al., 2017; Hansen et al., 2015, 2019; Shears et al., 2018; Tritten et al., 2017). It is reasonable to posit that specifically inhibiting EV secretion would obstruct the immunomodulatory capabilities of these parasites. Second, the pharmacological distruption of EV secretion does not perfectly correlate with the secretion of other ES products, hinting that the regulation of EV secretion may be distinct to that of other ES products and therefore differentially "druggable". IVM $(1.0 \mu \mathrm{M})$ inhibited EV secretion from mf stage B. malayi and B. pahangi after $24 \mathrm{hrs}$ by $46 \%$ and $40 \%$, respectively. In comparison, we found the same treatment inhibited protein secretion by B. malayi mf more modestly at $23 \%$. Further, whilst IVM $(1.0 \mu \mathrm{M})$ inhibited EV secretion in adult female B. malayi by $59 \%$ after 24 hrs, the same treatment had no significant effect on protein secretion from those worms. Clearly, more work is needed to understand how parasite secretions are regulated but moving forward it may be advisable to disentangle the broad panoply of ES products and investigate them individually to help better understand host-parasite interactions and particularly how drugs affect the secretion of parasite effector molecules.

Parasite motility has long been used as an assay to identify and measure the anthelmintic activity of compounds and as marker of parasite health and viability. Impaired motility alone, however, does not adequately account for the therapeutic effects of IVM in filarial disease. The in vitro IVM concentrations that are required to produce detrimental effects on gross filarial nematode motility are significantly higher than the bioavailable concentrations found in vivo after therapeutic administration (González Canga et al., 2008; Marcellino et al., 2012; Storey et al., 2014; Tompkins et al., 2010). Our data support this - the $\mathrm{IC}_{50}$ of IVM in the B. malayi adult female EV secretion assay was $7.7 \mathrm{nM}$ but was over $200 \mathrm{nM}$ for the motility assay. IVM inhibits EV secretion but not motility in key stages at therapeutically relevant concentrations, supporting inhibition of EV secretion as a component of IVM mode of action. IVM also exerted inhibitory effects on B. malayi adult females but not adult males, and larval stages. This stage- and sex-specific activity does correlate to the expression patterns of genes encoding subunits of glutamate-gated chloride channels 
bioRxiv preprint doi: https://doi org/10.1101/2020.07.20.212290; this version posted July 21, 2020. The copyright holder for this preprint (which was not certified by peer review) is the author/funder, who has granted bioRxiv a license to display the preprint in perpetuity. It is made available under aCC-BY-NC-ND 4.0 International license.

(GluCls), a proposed target for IVM (Arena et al., 1991, 1992). Li et al (2014) found that avr-14, a gene encoding a putative GluCl subunit in $B$. malayi, was expressed in both female and male reproductive tissues but consistently more strongly in female tissues (ovaries and surrounding body wall muscle) than male. This differential expression profile may help explain why EV secretion was inhibited in female worms but not male worms and may also point to reproductive structures as a source of these EVs in adult female worms. Proteomic analyses of EV cargo has proved valuable in identifying markers of tissue origin in other nematodes (Buck et al., 2014) but our previous nanoscale proteome profiling of $B$. malayi female and male EVs did not identify any clear markers supporting a reproductive tissue origin for these vesicles (Harischandra et al., 2018). A more focused investigation of the fluid found in these structures may prove more illuminating, as would demonstration that putative IVM targets are similarly expressed in reproductive tissues of adult female $B$. pahangi and A. suum to account for the potent IVM activity we noted in those species. Li et al, (2014) also observed tissue-specific avr-14 expression in embryonic stages within gravid females. This corroborates the findings of Moreno et al. (2014) who noted strong localization of avr-14 around the ES pore of B. malayi mfs, earmarking this structure as another, perhaps more predictable, site of EV secretion in this stage that lacks reproductive tissues or a through gut.

Whether these EVs have their biogenesis in reproductive tissues, the excretory system or some other secretory route, the pathways by which IVM inhibits their secretion is obscure and will require a more thorough description of the microscopic anatomy of key tissues and a better understanding of IVM targets expressed therein. For example, despite the recognition that parasitic nematode ES systems secrete a complex suite of molecules believed to be essential for successful parasitism (Allen \& Maizels, 2011; Hewitson et al., 2009; Hoerauf et al., 2005; van Riet et al., 2007), the ultrastructure and transcriptional topography of the ES pore region has largely been uninvestigated. The intersection between EVs as an important mechanism for host manipulation during infection, the inhibition of their secretion by IVM at therapeutically relevant concentrations 
and time frames, and the localization of putative IVM targets in critical stage-specific tissues, provides strong rationale for addressing this knowledge gap.

A significant outcome from the work presented here is the demonstration that EV secretion from adult female and $\mathrm{mf}$ stage filarial nematodes (the stages that one could argue are most relevant to LF control programs) can be quantified and the effect of extraneously applied compounds on this secretion measured. Using this assay, we detected an IVM-sensitive EV secretion phenotype that perhaps correlates better with therapeutically relevant IVM concentrations than does assaying parasite motility, and in our experience is a more convenient and reproducible assay than that used to measure protein secretion from these worms. It may also be a better predictor of IVM mode of action. If the therapeutic mechanism of action of IVM is to inhibit immunomodulatory protein secretion from $\mathrm{mf}$ parasites then albendazole, which has been reported to inhibit protein secretion from B. malayi $\mathrm{mf}$ faster and more comprehensively than IVM (Moreno et al., 2010) (although we did not observe this), should also be an effective microfilaricide. Albendazole, however, is ineffective against $\mathrm{mf}$ stage filarial nematodes (Critchley et al., 2005). This suggests inhibition of EV secretion may be a preferred characteristic of anti-filarial drugs and therefore assaying this phenotype would be of significance to future drug discovery efforts aimed at developing new antifilarial compounds, certainly those that function like IVM. In its favor, EV quantification would provide a consistent screening assay that would be comparable across different species of parasites, however, EV quantification is not high-throughput and does require additional EV isolation steps and specialized equipment for EV visualization. Recent technological advances may provide platforms that could be leveraged to streamline EV quantification assays and overcome these drawbacks. For example, we have contributed to an on-chip microfluidic device that utilizes a labelfree photonic crystal biosensor to detect and discriminate host EVs from those secreted by parasitic nematodes based on differential expression of EV surface markers (Wang et al., 2018). This type of platform combines minimal sample processing with high throughput potential and does not require EV labelling, overcoming the disadvantages of traditional EV quantification and could be leveraged 
bioRxiv preprint doi: https://doi org/10.1101/2020.07.20.212290; this version posted July 21, 2020. The copyright holder for this preprint (which was not certified by peer review) is the author/funder, who has granted bioRxiv a license to display the preprint in perpetuity. It is made available under aCC-BY-NC-ND 4.0 International license.

in drug discovery efforts centered on EV secretion as an assay endpoint. Another potential use for this type of platform are the early detection of parasite infection. The use of EVs as a nematode diagnostic has been seeded by the focus on EVs as diagnostic markers for cancer detection. Current advanced technologies involve using surface enhanced Raman scattering (SERS) or localized surface plasmon resonance to detect tumor-derived EVs in body fluids (Mehmet et al., 2017; Thakur et al., 2017; Zong et al., 2016). In addition, the miRNA cargo of EVs has been of interest as biomarkers for various cancers (Kosaka et al., 2019). Similarly, a microfluidic on-chip device has potential to identify parasite EVs from host biofluids. Current efforts towards this goal are aimed at identifying secreted parasite markers that that could be incorporated in such a design, or used in more simple assay formats such as PCR (Quintana et al., 2017; Tritten et al., 2014). Finally, the assay we describe here may be an example of a relatively simple in vitro assay to test or validate the emergence of anthelmintic resistance. The Fecal Egg Count Reduction Test is the gold standard for detecting resistance to anthelmintics like IVM. Alternative in vitro assays complement FECRT and include hatching and development assays, molecular tests and, of course, motility assays (Kotze \& Prichard, 2016). The EV secretion assay could be added to this list if it could reliably, and with sensitivity, detect resistance to drugs such as IVM in a standardized fashion. There is some evidence for this potential; we previously detected differences in IVM susceptibility based on EV secretion for two strains of canine heartworm, D. immitis (Harischandra et al., 2018).

Collectively, our data show that the secretion of EVs from different parasitic nematode species can be assayed and the effects of anthelmintic drugs or lead compounds on this physiological process can be measured. IVM consistently inhibited EV secretion against all species and most life stages investigated, with the exception of male worms; other anti-filarial drugs did not. These findings provide new insight into the stage-, sex- and species-specific pathways and pharmacological regulation of EV secretion in parasitic nematodes. The data is significant because, given the emerging immunomodulatory role of EVs at the host-parasite interface, it provides new evidence that the therapeutic mechanism of IVM, in part, involves inhibition of parasite EV secretion. 
bioRxiv preprint doi: https://doi.org/10.1101/2020.07.20.212290; this version posted July 21, 2020. The copyright holder for this preprint (which was not certified by peer review) is the author/funder, who has granted bioRxiv a license to display the preprint in perpetuity. It is made available under aCC-BY-NC-ND 4.0 International license.

\section{Disclosure of Interest}

544 The authors report no conflict of interest.

545 
bioRxiv preprint doi: https://doi org/10.1101/2020.07.20.212290; this version posted July 21, 2020. The copyright holder for this preprin (which was not certified by peer review) is the author/funder, who has granted bioRxiv a license to display the preprint in perpetuity. It is made available under aCC-BY-NC-ND 4.0 International license.

\section{References}

Allen, J. E., \& Maizels, R. M. (2011). Diversity and dialogue in immunity to helminths. Nature Reviews Immunology, 11(6), 375-388. https://doi.org/10.1038/nri2992

Arena, Joseph P., Liu, K. K., Paress, P. S., \& Cully, D. F. (1991). Avermectin-sensitive chloride currents induced by Caenorhabditis elegans RNA in Xenopus oocytes. Molecular Pharmacology, 40(3), 368-374.

Arena, Joseph P., Liu, K. K., Paress, P. S., Schaeffer, J. M., \& Cully, D. F. (1992). Expression of a glutamate-activated chloride current in Xenopus oocytes injected with Caenorhabditis elegans RNA: Evidence for modulation by avermectin. Molecular Brain Research, 15(3), 339-348. https://doi.org/10.1016/0169-328X(92)90127-W

Babu, S., \& Nutman, T. B. (2014). Immunology of lymphatic filariasis. Parasite Immunology, 36(8), 338-346. https://doi.org/10.1111/pim.12081

Bennuru, S., Semnani, R., Meng, Z., Ribeiro, J. M. C., Veenstra, T. D., \& Nutman, T. B. (2009). Brugia malayi Excreted/Secreted Proteins at the Host/Parasite Interface: Stage- and GenderSpecific Proteomic Profiling. PLOS Neglected Tropical Diseases, 3(4), e410. https://doi.org/10.1371/journal.pntd.0000410

Berrafato, T., Coates, R., Reaves, B. J., Kulke, D., \& Wolstenholme, A. J. (2019). Macrocyclic lactone anthelmintic-induced leukocyte binding to Dirofilaria immitis microfilariae: Influence of the drug resistance status of the parasite. International Journal for Parasitology: Drugs and Drug Resistance, 10, 45-50. https://doi.org/10.1016/j.ijpddr.2019.04.004

Bobrie, A., Colombo, M., Raposo, G., \& Théry, C. (2011). Exosome Secretion: Molecular Mechanisms and Roles in Immune Responses. Traffic, 12(12), 1659-1668. https://doi.org/10.1111/j.1600-0854.2011.01225.x

Buck, A. H., Coakley, G., Simbari, F., McSorley, H. J., Quintana, J. F., Le Bihan, T., Kumar, S., Abreu-Goodger, C., Lear, M., Harcus, Y., Ceroni, A., Babayan, S. A., Blaxter, M., Ivens, 
bioRxiv preprint doi: https://doi org/10.1101/2020.07.20.212290; this version posted July 21, 2020. The copyright holder for this preprint (which was not certified by peer review) is the author/funder, who has granted bioRxiv a license to display the preprint in perpetuity. It is made available under aCC-BY-NC-ND 4.0 International license.

A., \& Maizels, R. M. (2014). Exosomes secreted by nematode parasites transfer small RNAs to mammalian cells and modulate innate immunity. Nature Communications, 5(1), 5488. https://doi.org/10.1038/ncomms6488

Carithers, D. S. (2017). Examining the role of macrolides and host immunity in combatting filarial parasites. Parasites \& Vectors, 10(1), 182. https://doi.org/10.1186/s13071-017-2116-6

Carlisle, C. H., Atwell, R. B., \& Robinson, S. (1984). The effectiveness of levamisole hydrochloride against the microfilaria of Dirofilaria immitis. Australian Veterinary Journal, 61(9), 282-284. https://doi.org/10.1111/j.1751-0813.1984.tb06010.x

Catalano, M., \& O'Driscoll, L. (2020). Inhibiting extracellular vesicles formation and release: A review of EV inhibitors. Journal of Extracellular Vesicles, 9(1), 1703244. https://doi.org/10.1080/20013078.2019.1703244

Coakley, G., McCaskill, J. L., Borger, J. G., Simbari, F., Robertson, E., Millar, M., Harcus, Y., McSorley, H. J., Maizels, R. M., \& Buck, A. H. (2017). Extracellular Vesicles from a Helminth Parasite Suppress Macrophage Activation and Constitute an Effective Vaccine for Protective Immunity. Cell Reports, 19(8), 1545-1557. https://doi.org/10.1016/j.celrep.2017.05.001

Critchley, J., Addiss, D., Ejere, H., Gamble, C., Garner, P., \& Gelband, H. (2005). Albendazole for the control and elimination of lymphatic filariasis: Systematic review. Tropical Medicine \& International Health, 10(9), 818-825. https://doi.org/10.1111/j.1365-3156.2005.01458.x

Eichenberger, R. M., Ryan, S., Jones, L., Buitrago, G., Polster, R., Montes de Oca, M., Zuvelek, J., Giacomin, P. R., Dent, L. A., Engwerda, C. R., Field, M. A., Sotillo, J., \& Loukas, A. (2018). Hookworm Secreted Extracellular Vesicles Interact With Host Cells and Prevent Inducible Colitis in Mice. Frontiers in Immunology, 9. https://doi.org/10.3389/fimmu.2018.00850 
bioRxiv preprint doi: https://doi org/10.1101/2020.07.20.212290; this version posted July 21 , 2020. The copyright holder for this preprin (which was not certified by peer review) is the author/funder, who has granted bioRxiv a license to display the preprint in perpetuity. It is made available under aCC-BY-NC-ND 4.0 International license.

Eichenberger, R. M., Sotillo, J., \& Loukas, A. (2018). Immunobiology of parasitic worm extracellular vesicles. Immunology \& Cell Biology, 96(7), 704-713. https://doi.org/10.1111/imcb.12171

Eichenberger, R. M., Talukder, M. H., Field, M. A., Wangchuk, P., Giacomin, P., Loukas, A., \& Sotillo, J. (2018). Characterization of Trichuris muris secreted proteins and extracellular vesicles provides new insights into host-parasite communication. Journal of Extracellular Vesicles, 7(1), 1428004. https://doi.org/10.1080/20013078.2018.1428004

Geary, Timothy G., Sims, S. M., Thomas, E. M., Vanover, L., Davis, J. P., Winterrowd, C. A., Klein, R. D., Ho, N. F. H., \& Thompson, D. P. (1993). Haemonchus contortus: IvermectinInduced Paralysis of the Pharynx. Experimental Parasitology, 77(1), 88-96. https://doi.org/10.1006/expr.1993.1064

Geary, Timothy G., Woo, K., McCarthy, J. S., Mackenzie, C. D., Horton, J., Prichard, R. K., de Silva, N. R., Olliaro, P. L., Lazdins-Helds, J. K., Engels, D. A., \& Bundy, D. A. (2010). Unresolved issues in anthelmintic pharmacology for helminthiases of humans. International Journal for Parasitology, 40(1), 1-13. https://doi.org/10.1016/j.ijpara.2009.11.001

González Canga, A., Sahagún Prieto, A. M., Diez Liébana, M. J., Fernández Martínez, N., Sierra Vega, M., \& García Vieitez, J. J. (2008). The Pharmacokinetics and Interactions of Ivermectin in Humans-A Mini-review. The AAPS Journal, 10(1), 42-46. https://doi.org/10.1208/s12248-007-9000-9

Gu, H. Y., Marks, N. D., Winter, A. D., Weir, W., Tzelos, T., McNeilly, T. N., Britton, C., \& Devaney, E. (2017). Conservation of a microRNA cluster in parasitic nematodes and profiling of miRNAs in excretory-secretory products and microvesicles of Haemonchus contortus. PLOS Neglected Tropical Diseases, 11(11), e0006056. https://doi.org/10.1371/journal.pntd.0006056 Halliday, A., Guimaraes, A. F., Tyrer, H. E., Metuge, H. M., Patrick, C. N. W., Arnaud, K.-O. J., Kwenti, T. D. B., Forsbrook, G., Steven, A., Cook, D., Enyong, P., Wanji, S., Taylor, M. J., 
\& Turner, J. D. (2014). A murine macrofilaricide pre-clinical screening model for onchocerciasis and lymphatic filariasis. Parasites \& Vectors, 7(1), 472. https://doi.org/10.1186/s13071-014-0472-z

Hansen, Eline P., Fromm, B., Andersen, S. D., Marcilla, A., Andersen, K. L., Borup, A., Williams, A. R., Jex, A. R., Gasser, R. B., Young, N. D., Hall, R. S., Stensballe, A., Ovchinnikov, V., Yan, Y., Fredholm, M., Thamsborg, S. M., \& Nejsum, P. (2019). Exploration of extracellular vesicles from Ascaris suum provides evidence of parasite-host cross talk. Journal of Extracellular Vesicles, 8(1), 1578116. https://doi.org/10.1080/20013078.2019.1578116

Hansen, Eline P., Kringel, H., Williams, A. R., \& Nejsum, P. (2015). SECRETION OF RNACONTAINING EXTRACELLULAR VESICLES BY THE PORCINE WHIPWORM, TRICHURIS SUIS. The Journal of Parasitology, 101(3), 336-340. JSTOR.

Harischandra, H., Yuan, W., Loghry, H. J., Zamanian, M., \& Kimber, M. J. (2018). Profiling extracellular vesicle release by the filarial nematode Brugia malayi reveals sex-specific differences in cargo and a sensitivity to ivermectin. PLOS Neglected Tropical Diseases, 12(4), e0006438. https://doi.org/10.1371/journal.pntd.0006438

Harnett, M. M., Deehan, M. R., Williams, D. M., \& Harnett, W. (1998). Induction of signalling anergy via the $\mathrm{T}$-cell receptor in cultured Jurkat $\mathrm{T}$ cells by pre-exposure to a filarial nematode secreted product. Parasite Immunology, 20(11), 551-563. https://doi.org/10.1046/j.1365-3024.1998.00181.x

Harrow, I. D., \& Gration, K. A. F. (1985). Mode of action of the anthelmintics morantel, pyrantel and levamisole on muscle cell membrane of the nematode Ascaris suum. Pesticide Science, 16(6), 662-672. https://doi.org/10.1002/ps.2780160612

Hewitson, J. P., Grainger, J. R., \& Maizels, R. M. (2009). Helminth immunoregulation: The role of parasite secreted proteins in modulating host immunity. Molecular and Biochemical Parasitology, 167(1), 1-11. https://doi.org/10.1016/j.molbiopara.2009.04.008 
bioRxiv preprint doi: https://doi org/10.1101/2020.07.20.212290; this version posted July 21, 2020. The copyright holder for this preprint (which was not certified by peer review) is the author/funder, who has granted bioRxiv a license to display the preprint in perpetuity. It is made available under aCC-BY-NC-ND 4.0 International license.

Hewitson, J. P., Harcus, Y. M., Curwen, R. S., Dowle, A. A., Atmadja, A. K., Ashton, P. D., Wilson, A., \& Maizels, R. M. (2008). The secretome of the filarial parasite, Brugia malayi: Proteomic profile of adult excretory-secretory products. Molecular and Biochemical Parasitology, 160(1), 8-21. https://doi.org/10.1016/j.molbiopara.2008.02.007

Hoerauf, A., Satoguina, J., Saeftel, M., \& Specht, S. (2005). Immunomodulation by filarial nematodes. Parasite Immunology, 27(10-11), 417-429. https://doi.org/10.1111/j.13653024.2005.00792.x

Hoy, A. M., Lundie, R. J., Ivens, A., Quintana, J. F., Nausch, N., Forster, T., Jones, F., Kabatereine, N. B., Dunne, D. W., Mutapi, F., MacDonald, A. S., \& Buck, A. H. (2014). Parasite-derived microRnas in host serum as novel biomarkers of helminth infection. PLoS Neglected Tropical Diseases, 8(2). Gale Academic OneFile. https://link.gale.com/apps/doc/A364854680/AONE?u=iastu_main\&sid=zotero\&xid=72d7c0 d1

Johnstone, R. M., Adam, M., Hammond, J. R., Orr, L., \& Turbide, C. (1987). Vesicle formation during reticulocyte maturation. Association of plasma membrane activities with released vesicles (exosomes). Journal of Biological Chemistry, 262(19), 9412-9420.

Kaushal, N. A., Hussain, R., Nash, T. E., \& Ottesen, E. A. (1982). Identification and characterization of excretory-secretory products of Brugia malayi, adult filarial parasites. The Journal of Immunology, 129(1), 338-343.

Kosaka, N., Kogure, A., Yamamoto, T., Urabe, F., Usuba, W., Prieto-Vila, M., \& Ochiya, T. (2019). Exploiting the message from cancer: The diagnostic value of extracellular vesicles for clinical applications. Experimental \& Molecular Medicine, 51(3), 1-9. https://doi.org/10.1038/s12276-019-0219-1

Kotze, A. C., \& Prichard, R. K. (2016). Chapter Nine - Anthelmintic Resistance in Haemonchus contortus: History, Mechanisms and Diagnosis. In R. B. Gasser \& G. V. Samson- 
bioRxiv preprint doi: https://doi org/10.1101/2020.07.20.212290; this version posted July 21, 2020. The copyright holder for this preprint (which was not certified by peer review) is the author/funder, who has granted bioRxiv a license to display the preprint in perpetuity. It is made available under aCC-BY-NC-ND 4.0 International license.

Himmelstjerna (Eds.), Advances in Parasitology (Vol. 93, pp. 397-428). Academic Press. https://doi.org/10.1016/bs.apar.2016.02.012

Lal, R. B., Kumaraswami, V., Steel, C., \& Nutman, T. B. (1990). Phosphocholine-Containing Antigens of Brugia Malayi Nonspecifically Suppress Lymphocyte Function. The American Journal of Tropical Medicine and Hygiene, 42(1), 56-64. https://doi.org/10.4269/ajtmh.1990.42.56

Lee, Y., EL Andaloussi, S., \& Wood, M. J. A. (2012). Exosomes and microvesicles: Extracellular vesicles for genetic information transfer and gene therapy. Human Molecular Genetics, 21(R1), R125-R134. https://doi.org/10.1093/hmg/dds317

Maclean, M. J., Savadelis, M. D., Coates, R., Dzimianski, M. T., Jones, C., Benbow, C., Storey, B. E., Kaplan, R. M., Moorhead, A. R., \& Wolstenholme, A. J. (2017). Does evaluation of in vitro microfilarial motility reflect the resistance status of Dirofilaria immitis isolates to macrocyclic lactones? Parasites \& Vectors, 10(2), 480. https://doi.org/10.1186/s13071-017$2436-6$

Marcellino, C., Gut, J., Lim, K. C., Singh, R., McKerrow, J., \& Sakanari, J. (2012). WormAssay: A Novel Computer Application for Whole-Plate Motion-based Screening of Macroscopic Parasites. PLOS Neglected Tropical Diseases, 6(1), e1494. https://doi.org/10.1371/journal.pntd.0001494

Martin, R. J. (1997). Modes of action of anthelmintic drugs. The Veterinary Journal, 154(1), 11-34. https://doi.org/10.1016/S1090-0233(05)80005-X

Mehmet, K., R, M. E., Aysun, K., \& Sebastian, W.-H. (2017). Fundamentals and applications of SERS-based bioanalytical sensing. Nanophotonics, 6(5), 831-852. https://doi.org/10.1515/nanoph-2016-0174

Mills, J. N., \& Amis, T. C. (1975). Levamisole as a Microfilaricidal Agent in the Control of Canine Dirofilariasis. Australian Veterinary Journal, 51(6), 310-314. https://doi.org/10.1111/j.1751-0813.1975.tb06962.x 
bioRxiv preprint doi: https://doi org/10.1101/2020.07.20.212290; this version posted July 21, 2020. The copyright holder for this preprint (which was not certified by peer review) is the author/funder, who has granted bioRxiv a license to display the preprint in perpetuity. It is made available under aCC-BY-NC-ND 4.0 International license.

Moreno, Y., Nabhan, J. F., Solomon, J., Mackenzie, C. D., Geary, T. G., \& Campbell, W. C. (2010). Ivermectin disrupts the function of the excretory-secretory apparatus in microfilariae of Brugia malayi. Proceedings of the National Academy of Sciences of the United States of America, 107(46), 20120-20125. JSTOR.

Mostafa, E., Storey, B., Farghaly, A. M., Afify, H. A. E.-H., Taha, A. A. E.-R., \& Wolstenholme, A. J. (2015). Transient effects of levamisole on Brugia malayi microfilariae. Invertebrate Neuroscience, 15(3), 5. https://doi.org/10.1007/s10158-015-0181-0

Pastrana, D. V., Raghavan, N., FitzGerald, P., Eisinger, S. W., Metz, C., Bucala, R., Schleimer, R. P., Bickel, C., \& Scott, A. L. (1998). Filarial Nematode Parasites Secrete a Homologue of the Human Cytokine Macrophage Migration Inhibitory Factor. Infection and Immunity, 66(12), 5955-5963. https://doi.org/10.1128/IAI.66.12.5955-5963.1998

Quintana, J. F., Babayan, S. A., \& Buck, A. H. (2017). Small RNAs and extracellular vesicles in filarial nematodes: From nematode development to diagnostics. Parasite Immunology, 39(2), e12395. https://doi.org/10.1111/pim.12395

Raposo, G., Nijman, H. W., Stoorvogel, W., Liejendekker, R., Harding, C. V., Melief, C. J., \& Geuze, H. J. (1996). B lymphocytes secrete antigen-presenting vesicles. Journal of Experimental Medicine, 183(3), 1161-1172. https://doi.org/10.1084/jem.183.3.1161

Riaz, F., \& Cheng, G. (2017). Exosome-like vesicles of helminths: Implication of pathogenesis and vaccine development. Annals of Translational Medicine, 5(7), 22. https://doi.org/10.21037/atm.2017.03.45

Robertson, A. P., Buxton, S. K., \& Martin, R. J. (2013). Whole-cell patch-clamp recording of nicotinic acetylcholine receptors in adult Brugia malayi muscle. Parasitology International, 62(6), 616-618. https://doi.org/10.1016/j.parint.2013.03.008

Semnani, R. T., Keiser, P. B., Coulibaly, Y. I., Keita, F., Diallo, A. A., Traore, D., Diallo, D. A., Doumbo, O. K., Traore, S. F., Kubofcik, J., Klion, A. D., \& Nutman, T. B. (2006). Filaria- 
bioRxiv preprint doi: https://doi org/10.1101/2020.07.20.212290; this version posted July 21, 2020. The copyright holder for this preprint (which was not certified by peer review) is the author/funder, who has granted bioRxiv a license to display the preprint in perpetuity. It is made available under aCC-BY-NC-ND 4.0 International license.

Induced Monocyte Dysfunction and Its Reversal following Treatment. Infection and Immunity, 74(8), 4409-4417. https://doi.org/10.1128/IAI.01106-05

Shears, R. K., Bancroft, A. J., Hughes, G. W., Grencis, R. K., \& Thornton, D. J. (2018). Extracellular vesicles induce protective immunity against Trichuris muris. Parasite Immunology, 40(7), e12536. https://doi.org/10.1111/pim.12536

Storey, B., Marcellino, C., Miller, M., Maclean, M., Mostafa, E., Howell, S., Sakanari, J., Wolstenholme, A., \& Kaplan, R. (2014). Utilization of computer processed high definition video imaging for measuring motility of microscopic nematode stages on a quantitative scale: “The Worminator." International Journal for Parasitology: Drugs and Drug Resistance, 4(3), 233-243. https://doi.org/10.1016/j.ijpddr.2014.08.003

Thakur, A., Qiu, G., Ng, S.-P., Guan, J., Yue, J., Lee, Y., \& Wu, C.-M. L. (2017). Direct detection of two different tumor-derived extracellular vesicles by SAM-AuNIs LSPR biosensor. Biosensors and Bioelectronics, 94, 400-407. https://doi.org/10.1016/j.bios.2017.03.036

Thery, C., Zitvogel, L., \& Amigorena, S. (2002). Exosomes: Composition, biogenesis and function. Nature Reviews Immunology, 2(8), 569-. Gale Academic OneFile.

Tompkins, J. B., Stitt, L. E., \& Ardelli, B. F. (2010). Brugia malayi: In vitro effects of ivermectin and moxidectin on adults and microfilariae. Experimental Parasitology, 124(4), 394-402. https://doi.org/10.1016/j.exppara.2009.12.003

Tritten, L., Burkman, E., Moorhead, A., Satti, M., Geary, J., Mackenzie, C., \& Geary, T. (2014). Detection of circulating parasite-derived microRNAs in filarial infections. PLoS Neglected Tropical Diseases, 8(7). Gale Academic OneFile. https://link.gale.com/apps/doc/A383328488/AONE?u=iastu_main\&sid=zotero\&xid=960749 $0 \mathrm{a}$

Tritten, L., Clarke, D., Timmins, S., McTier, T., \& Geary, T. G. (2016). Dirofilaria immitis exhibits sex- and stage-specific differences in excretory/secretory miRNA and protein profiles. Veterinary Parasitology, 232, 1-7. https://doi.org/10.1016/j.vetpar.2016.11.005 
bioRxiv preprint doi: https://doi org/10.1101/2020.07.20.212290; this version posted July 21, 2020. The copyright holder for this preprint (which was not certified by peer review) is the author/funder, who has granted bioRxiv a license to display the preprint in perpetuity. It is made available under aCC-BY-NC-ND 4.0 International license.

Tritten, L., Tam, M., Vargas, M., Jardim, A., Stevenson, M. M., Keiser, J., \& Geary, T. G. (2017). Excretory/secretory products from the gastrointestinal nematode Trichuris muris. Experimental Parasitology, 178, 30-36. https://doi.org/10.1016/j.exppara.2017.05.003

Tzelos, T., Matthews, J. B., Buck, A. H., Simbari, F., Frew, D., Inglis, N. F., McLean, K., Nisbet, A. J., Whitelaw, C. B. A., Knox, D. P., \& McNeilly, T. N. (2016). A preliminary proteomic characterisation of extracellular vesicles released by the ovine parasitic nematode, Teladorsagia circumcincta. Veterinary Parasitology, 221, 84-92. https://doi.org/10.1016/j.vetpar.2016.03.008

Valadi, H., Ekstrom, K., Bossios, A., Sjostrand, M., Lee, J. J., \& Lotvall, J. O. (2007). Exosomemediated transfer of mRNAs and microRNAs is a novel mechanism of genetic exchange between cells. Nature Cell Biology, 9(6), 654-. Gale Academic OneFile.

van Riet, E., Hartgers, F. C., \& Yazdanbakhsh, M. (2007). Chronic helminth infections induce immunomodulation: Consequences and mechanisms. Immunobiology, 212(6), 475-490. https://doi.org/10.1016/j.imbio.2007.03.009

Vlassov, A. V., Magdaleno, S., Setterquist, R., \& Conrad, R. (2012). Exosomes: Current knowledge of their composition, biological functions, and diagnostic and therapeutic potentials. Biochimica et Biophysica Acta (BBA) - General Subjects, 1820(7), 940-948. https://doi.org/10.1016/j.bbagen.2012.03.017

Wang, Y., Yuan, W., Kimber, M., Lu, M., \& Dong, L. (2018). Rapid Differentiation of Host and Parasitic Exosome Vesicles Using Microfluidic Photonic Crystal Biosensor. ACS Sensors, 3(9), 1616-1621. https://doi.org/10.1021/acssensors.8b00360

Wolstenholme, Adrian J., Maclean, M. J., Coates, R., McCoy, C. J., \& Reaves, B. J. (2016). How do the macrocyclic lactones kill filarial nematode larvae? Invertebrate Neuroscience, 16(3), 7. https://doi.org/10.1007/s10158-016-0190-7 
bioRxiv preprint doi: https://doi.org/10.1101/2020.07.20.212290; this version posted July 21, 2020. The copyright holder for this preprint

(which was not certified by peer review) is the author/funder, who has granted bioRxiv a license to display the preprint in perpetuity. It is made available under aCC-BY-NC-ND 4.0 International license.

774 Wolstenholme, Adrian J., \& Rogers, A. T. (2005). Glutamate-gated chloride channels and the mode of action of the avermectin/milbemycin anthelmintics. Parasitology, 131(S1), S85-S95. https://doi.org/10.1017/S0031182005008218

World Health Organization. (2019). World Health Organization model list of essential medicines: 21 st list 2019 (WHO/MVP/EMP/IAU/2019.06). Article WHO/MVP/EMP/IAU/2019.06. https://apps.who.int/iris/handle/10665/325771 report, 2018. Weekly Epidemiological Record, 94(41), 457-472. detection of tumor-derived exosomes using magnetic nanobeads and SERS nanoprobes. 
A

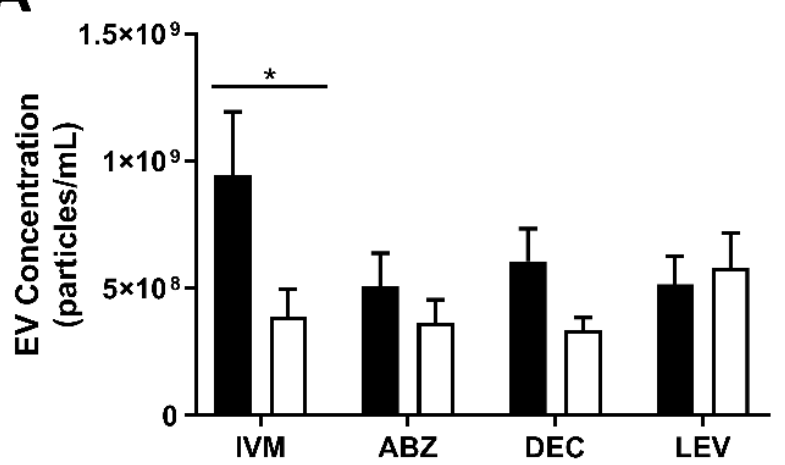

C

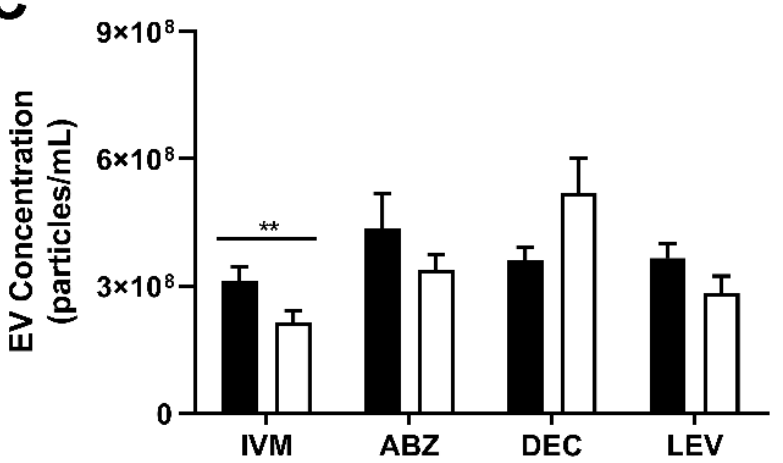

B

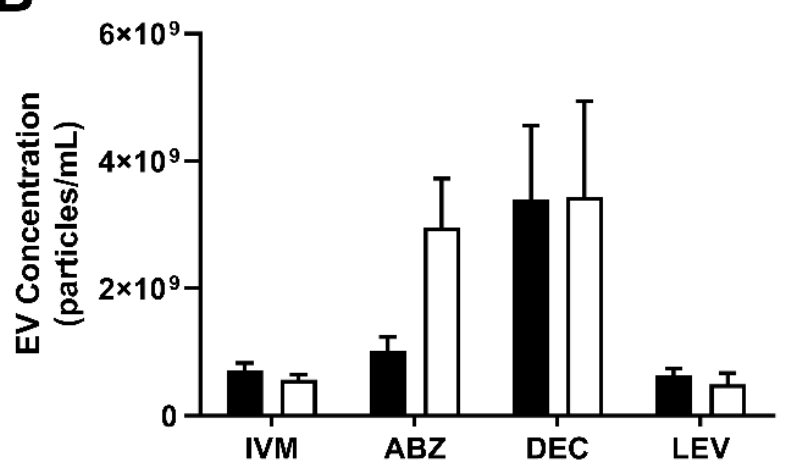

D

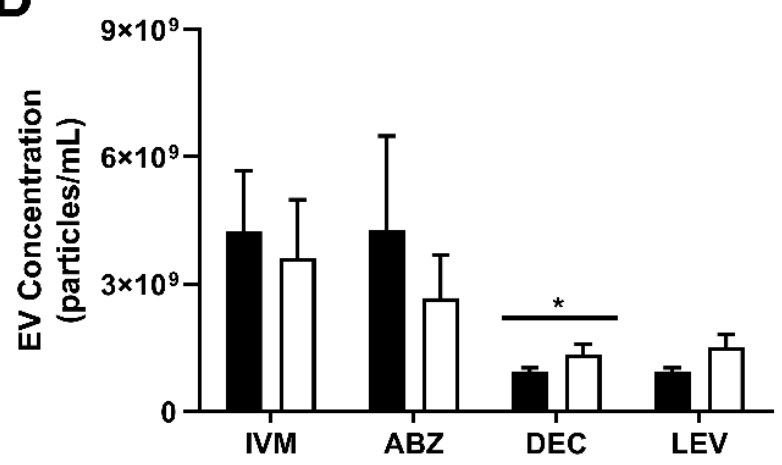

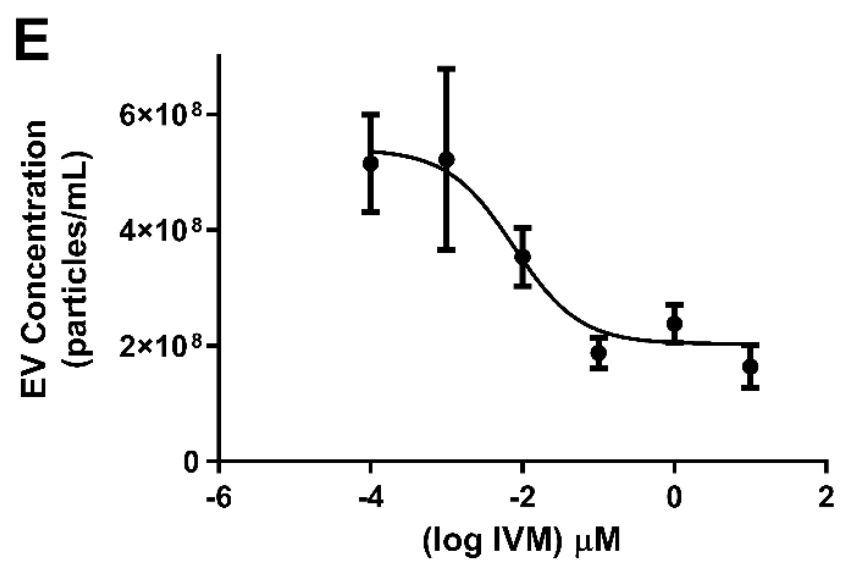

Figure 1. Ivermectin inhibits Brugia malayi EV secretion in a stage- and sex- specific manner B. malayi life stages were cultured at $37^{\circ} \mathrm{C}$ in RPMI with either drug $(1.0 \mu \mathrm{M})$ or DMSO (vehicle control). Media was collected after $24 \mathrm{hrs}$ and EVs were isolated and quantified. 1.0 $\mu \mathrm{M}$ IVM significantly reduced EV secretion from adult female worms (A) and L3 stage parasites (C) but not from adult males (B) or microfilaria (D). Albendazole (ABZ), diethylcarbamazine (DEC) or levamisole (LEV) had no effect on EV secretion from any life stage except in microfilaria, where DEC increased EV secretion. (E) The $\mathrm{IC}_{50}$ for IVM on adult female worms was determined to be 

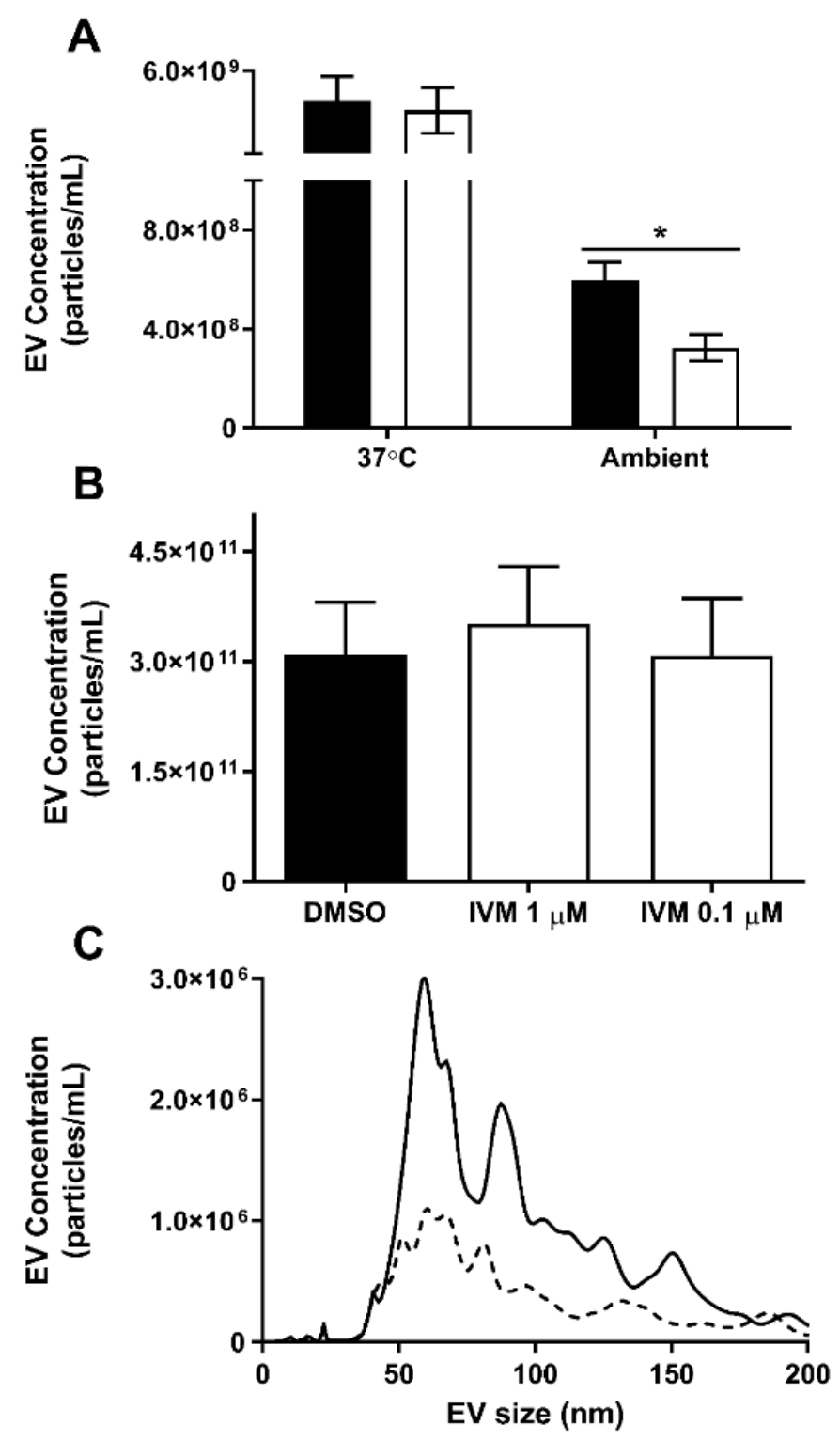

Figure 2. Ivermectin activity against mf stage worms is temperature dependent and does not alter EV biogenesis

B. malayi life stages were cultured at $37^{\circ} \mathrm{C}$ in RPMI with either drug $(1.0 \mu \mathrm{M})$ or DMSO (vehicle control). Media was collected after $24 \mathrm{hrs}$ and EVs were isolated and quantified. The activity of IVM on B. malayi microfilariae was temperature dependent (A). Inhibition of EV secretion occurred at ambient temperature, but not at $37^{\circ} \mathrm{C}$. To investigate IVM mechanism of inhibition Sf 21 cells were treated with either DMSO, high $(1.0 \mu \mathrm{M})$ or low $(0.1 \mu \mathrm{M})$ concentrations of IVM. Spent media was collected after 24 hrs and EVs were collected and quantified. (B) there were no differences in the ability of DMSO control, high, or low concentrations of IVM treated cells to secrete EVs. To further investigate the potential effect on biogenesis the size of EVs secreted from adult female parasites were evaluated (C). The mean size of EVs secreted from adult females was highly similar between DMSO and IVM treated parasites. $\mathrm{N}=3$ (minimum). ${ }^{*} \mathrm{P}<0.05$. $\square=$ Treatment. Solid line $=$ DMSO, Dashed line $=$ IVM. 
A

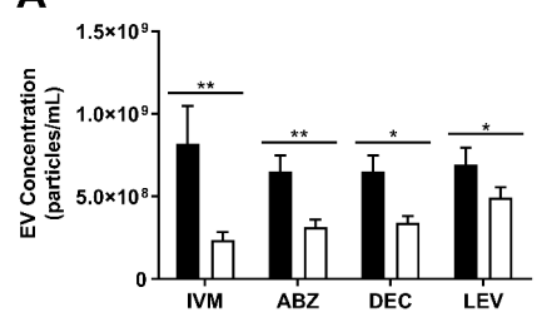

C

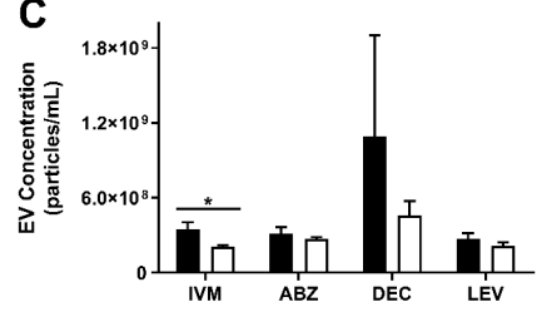

E

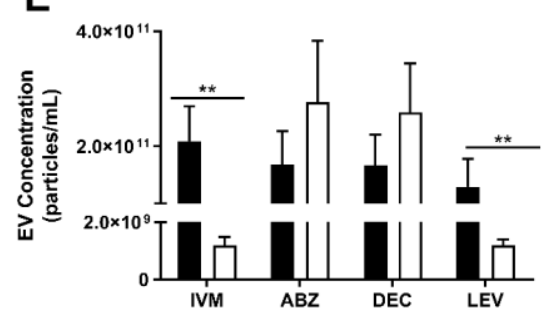

G

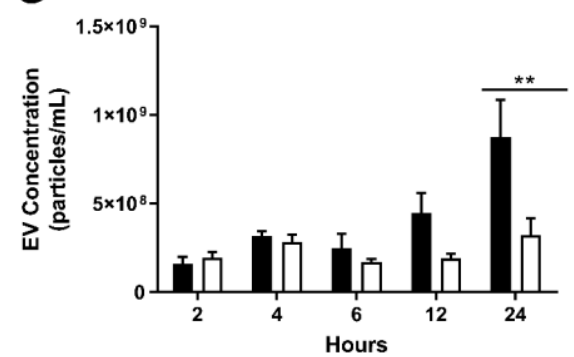

B
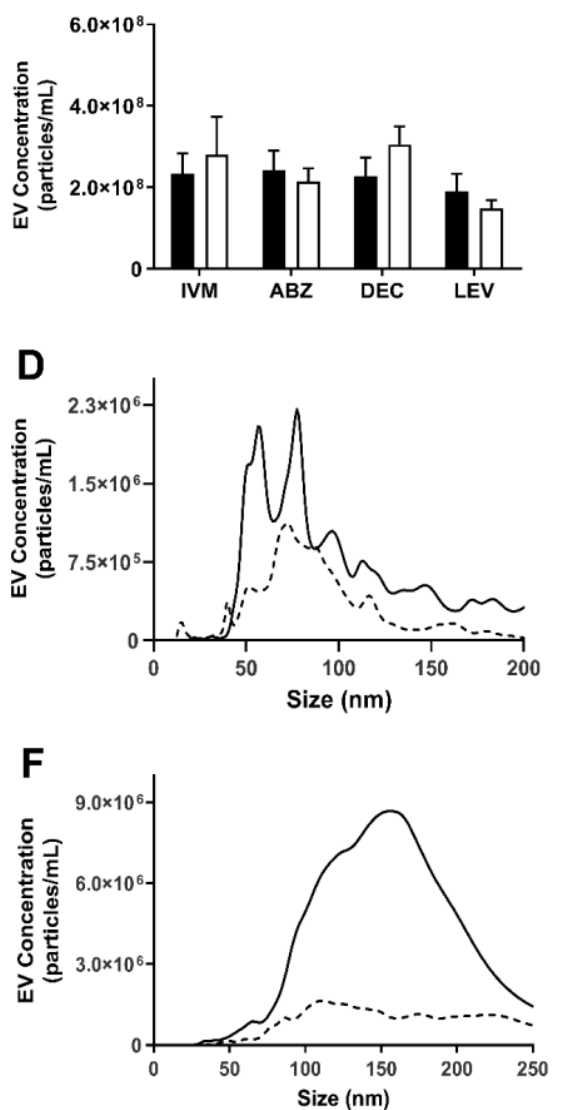

H

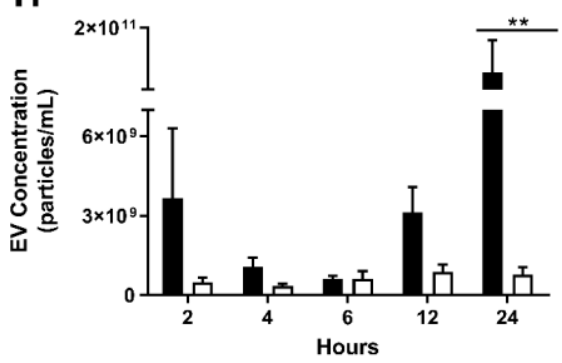

813

Figure 3. Ivermectin has broad inhibitory effects across filarial and gastrointestinal parasites B. pahangi life stages in RPMI and adult female A. suum in Ascaris Ringers solution were cultured at $37^{\circ} \mathrm{C}$ with either drug $(1.0 \mathrm{uM})$ or DMSO (vehicle control). Media was collected after $24 \mathrm{hrs}$ and EVs were isolated and quantified. $1.0 \mu \mathrm{M}$ IVM, ABZ, DEC, and LEV all significantly inhibited EV secretion from B. pahangi adult female parasites (A) while only IVM significantly reduced EV secretion in the microfilariae life stage (C). No treatment had any effect on EV secretion from $B$. pahangi adult male parasites (B). For A. suum adult females, both IVM and LEV significantly inhibited EV secretion (E). The size distribution of EVs secreted from DMSO and IVM treated $B$. pahangi adult females (D) and A. suum adult females (F) were highly similar indicating that IVM does not affect the physical characteristics of EVs produced (F). IVM rapidly inhibits EV secretion from adult female $B$. pahangi and $A$. suum $24 \mathrm{hrs}$ post-treatment (G-H). $\mathrm{N}=3$ (minimum). Mean \pm SEM, $* \mathrm{P}<0.05, * * \mathrm{P}<0.01$. = DMSO, $\square=$ Treatment. Solid line $=$ DMSO, Dashed line $=$ IVM. 
A
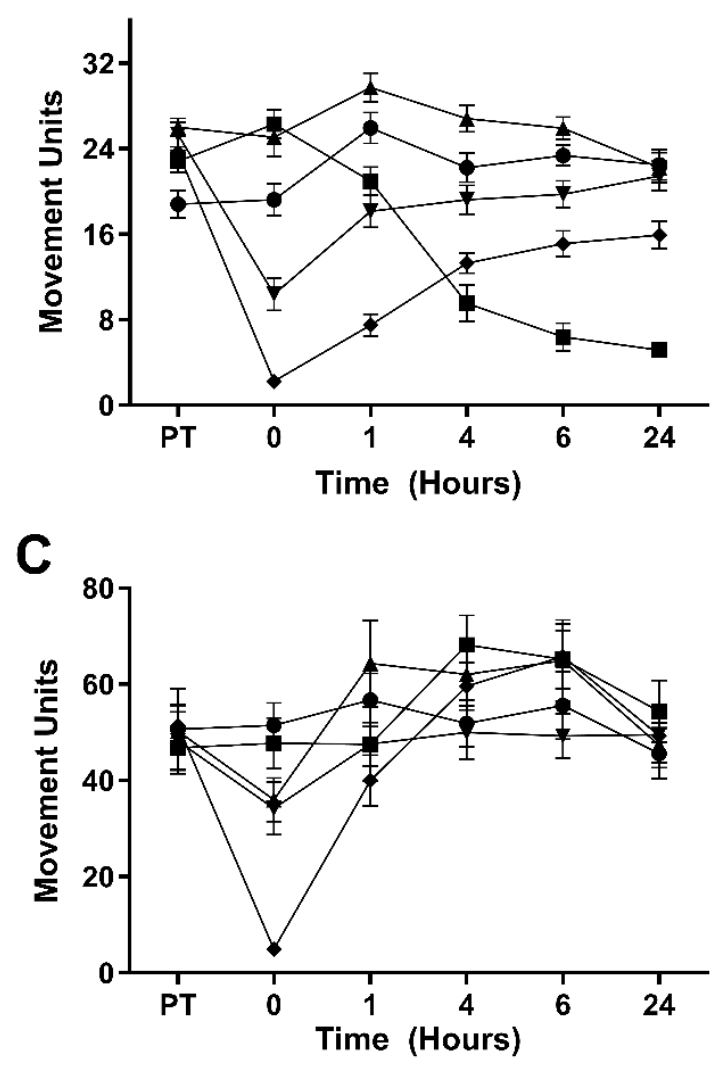

B

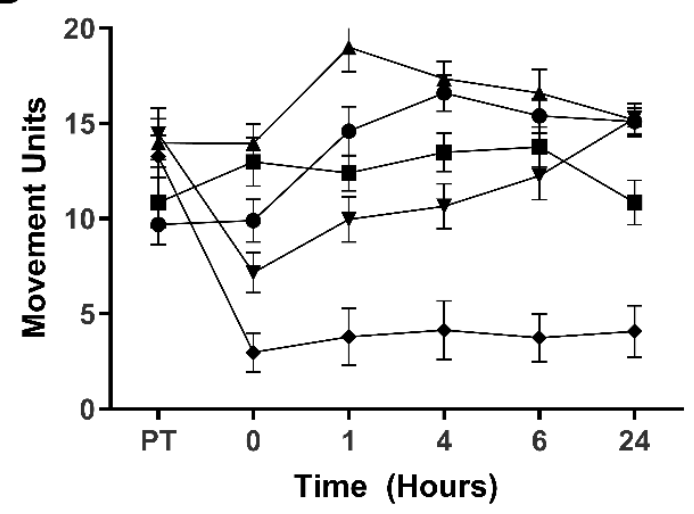

D

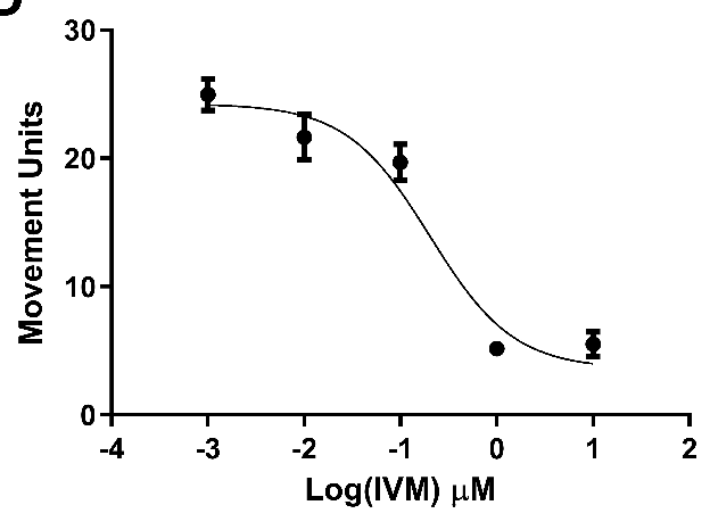

Figure 4. Ivermectin inhibition of EV secretion is not driven by loss of gross motor function

Single adult or 10 L3 stage Brugia malayi parasites were cultured in a 24-well plate with either 1.0 $\mu \mathrm{M}$ drug or DMSO (vehicle control). Video recordings of worms were taken at timepoints ranging from pre-treatment to $24 \mathrm{hrs}$ using the Worminator system. (A) IVM significantly reduced adult female B. malayi motility as compared to control from 4-24 hrs post treatment $(\mathrm{p}<0.0001)$. However, further investigation revealed that more therapeutically relevant concentrations of IVM did not affect adult female motility. The $\mathrm{IC}_{50}$ for IVM on adult female parasites was determined to be 203 nM. (D). DEC significantly reduced adult female motility immediately upon treatment and one hour post treatment $(\mathrm{p}<0.001)$. LEV significantly reduced adult female motility from 0-24 hrs $(\mathrm{p}<0.0001-\mathrm{p}<0.01)$ though the parasites began to recover after initial treatment. (B) DEC significantly reduced adult male motility from one to four hours post treatment $(p<0.05, p<0.01)$ and IVM began to reduce motility at $24 \mathrm{hrs}$ post treatment $(\mathrm{p}<0.05)$. LEV significantly reduced motility with no recovery from $0-24$ hrs post treatment ( $p<0.0001$ ). (C) LEV significantly reduced L3 stage motility immediately upon treatment $(\mathrm{p}<0.0001)$, but the parasites quickly recovered within one hr. $\mathrm{N}=11$ (minimum), Mean $\pm \mathrm{SEM} . \bullet=\mathrm{DMSO}, \boldsymbol{\bullet}=\mathrm{IVM}, \boldsymbol{\Delta}=\mathrm{ABZ}, \boldsymbol{\nabla}=\mathrm{DEC}, \bullet=$ LEV 
A

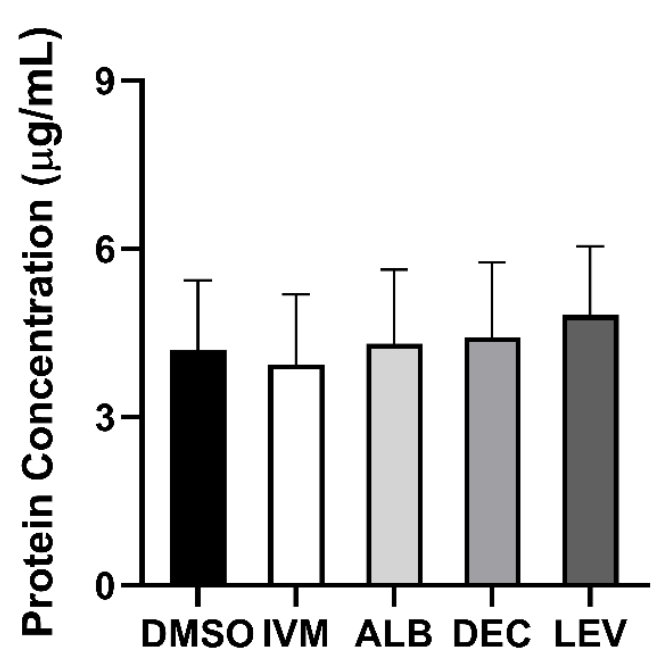

C

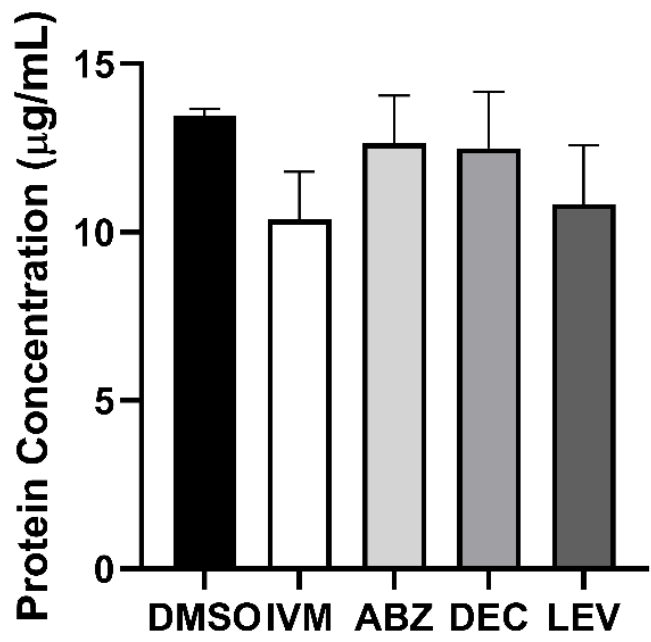

B

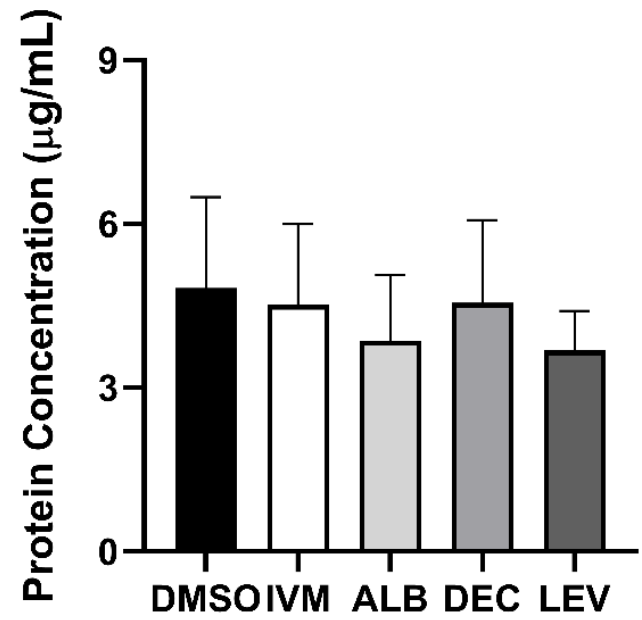

D

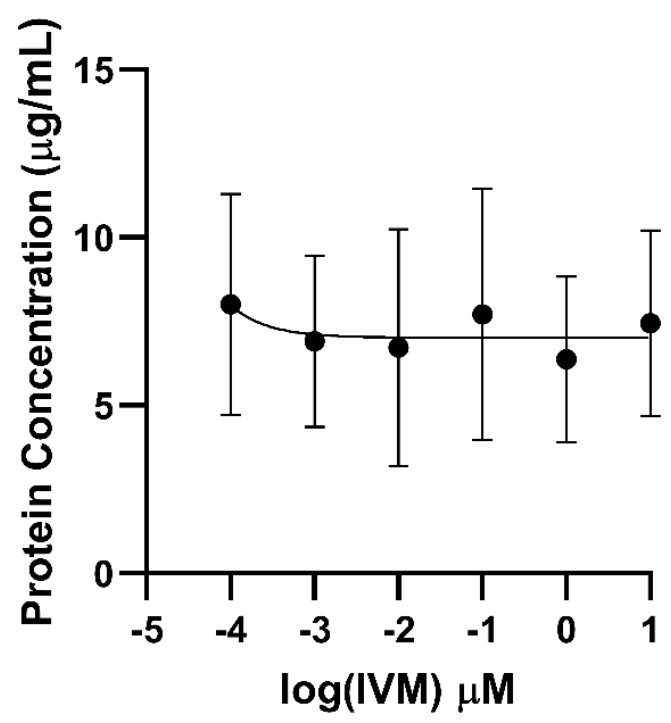

844

Figure 5. EV and protein secretion are differentially affected by ivermectin

Single adult or 100,000 microfilariae Brugia malayi parasites were cultured per well of a 24-well plate with either drug $(1.0 \mu \mathrm{M})$ or DMSO $(0.01 \%)$ for $24 \mathrm{hrs}$. Spent media was collected and proteins were concentrated and washed. Protein concentration was determined by absorbance at 562 nm. No drug had any effect on protein secretion from B. malayi adult females (A). B. malayi adult males (B) had a decrease in protein secretion due to LEV though not statistically significant. Microfilariae protein secretion $(C)$ was inhibited by ivermectin ( $p=0.0535)$. (D) A dose response curve for IVM on adult female parasites showed no effect from any concentration of IVM (10 $\mu \mathrm{M}-$ $0.1 \mathrm{nM}) . \mathrm{N}=5$ (minimum), Mean \pm SEM. 